\title{
Structural legacies and the motherhood penalty: How past societal contexts shape mothers' employment outcomes in reunified Germany
}

\author{
$05 / 22 / 2020$ \\ (Preliminary Version - please do not cite) \\ Matthias Collischon ${ }^{1}$, Andreas Eberl ${ }^{1}$, Malte Reichelt ${ }^{2,3}$ \\ ${ }^{1}$ FAU Erlangen Nuremberg; ${ }^{2}$ New York University Abu Dhabi (NYUAD); ${ }^{3}$ Institute for Employment Research (IAB)
}

\begin{abstract}
Motherhood penalties vary strongly across societal contexts. While most studies that aim to explain such differences focus on institutions, a smaller literature refers to the influence of cultural norms or a complex interaction between the two. Empirically, however, it is yet unclear if such norms play a role and how they — jointly with institutions — contribute to motherhood penalties. We make use of a unique historical setting that allows us to assess how societal contexts affect maternal work preferences and labor market outcomes in the short- and long-run. Germany's division into socialist East and parliamentary democratic West led to considerably different gender norms. But German reunification in 1990 mostly realigned gendered institutions. Using data from the German Socio-Economic Panel (SOEP), we show that East and West German mothers' preferred and realized labor force participation and working hours nevertheless remain divergent. We then focus on East German women who moved to the West during and after the country's transitionary period. Despite moving to a context with more conservative gender norms, East German mothers in the West retain and fulfill their work preferences. Our findings imply that it is the structural legacy of past norms and institutions, not current ones, that shapes maternal work preferences and thus pave the way for motherhood penalties. Moreover, societal norms at the time of childbirth do not directly affect mothers' labor force participation, working hours, or wages. Gendered outcomes in the labor market are thus highly dependent on institutional and normative changes across cohorts.
\end{abstract}

Keywords: motherhood penalty, gender wage gap, German reunification, work preferences, societal norms, institutions 


\section{Introduction}

The higher labor market participation rates for women and the narrowing of the gender pay gap have been remarkable advances of many societies over the past decades. However, since the mid-1990s the movement toward gender pay equity in the U.S. and other industrialized countries has slowed down. Women's wages in the U.S. have plateaued at around 83 percent, leading researchers to speak of a "stalled gender revolution" (Blau \& Kahn, 2006; England, 2010; England, Levine, \& Mishel, 2020; Gerson, 2009).

One of the main drivers of gender pay gaps are motherhood penalties, the reduction in wages that mothers face compared to non-mothers (Budig \& England, 2001; England, 2005; Harkness \& Waldfogel, 2003). The share of the motherhood penalty on the overall gender pay gap has drastically increased over the past three to four decades (Kleven, Landais, \& Søgaard, 2019) as advancements in other parts of gender inequality have not been matched and the motherhood penalties remained stable over time (Avellar \& Smock, 2003; Waldfogel, 1998b). Employed mothers are thus now the group that accounts for most of the gender pay gap (Waldfogel, 1998a). But motherhood penalties are not equally pronounced across all countries (Harkness \& Waldfogel, 2003; Sigle-Rushton \& Waldfogel, 2007; Stier, Lewin-Epstein, \& Braun, 2001), raising the questions as to what societal conditions alleviate or contribute to mothers' disadvantages in the labor market.

Most studies aiming to explain the contextual effects on motherhood penalties refer to institutional differences between countries (Budig, Misra, \& Boeckmann, 2012; Gangl \& Ziefle, 2009; Harkness \& Waldfogel, 2003; Sigle-Rushton \& Waldfogel, 2007; Stier et al., 2001). Much of the literature assumes rational actors and predicts that mothers and employers act according to the policies and institutions that are being put in place (Kremer, 2007). A second smaller strain of literature, however, argues that institutions cannot fully explain the country differences and that institutions and the cultural context in conjuncture serve as a better explanation for motherhood penalties (Boeckmann, Misra, \& Budig, 2014; Budig et al., 2012; Gangl \& Ziefle, 2009; Pfau-Effinger, 2004; Sigle-Rushton \& Waldfogel, 2007). These studies argue that societal norms shape mothers' employment and earnings as well as the gendered division of household labor (Budig et al., 2012; Cooke, 2006; Kremer, 2007; PfauEffinger, 2004; Pfau-Effinger, 1998; van der Lippe, de Ruijter, de Ruijter, \& Raub, 2011). For one, because societal norms serve as a basis for institutions and thus affect mothers' employment outcomes through the creation of policies (Kremer, 2006, 2007; Lewis, 1992; Orloff, 1996). But norms can also directly affect motherhood penalties, for example if employers discriminate against mothers because the cultural understandings of the motherhood role exist in tension with the cultural understandings of the "ideal worker" role (Correll, Bernard, \& Paik, 2007; Hipp, 2019) or if mothers seeking work face informal sanctions from their community (Uunk, 2015) . 
We argue that previous literature exploring the contextual effects on motherhood penalties suffers from two shortcomings. First, while previous literature mainly focuses on the effects of institutions and norms at the time of motherhood, we argue that the societal context at the time of mothers' youth and adolescence is crucial—if not more important—-for later labor market outcomes. Gender role attitudes and beliefs are shaped early in life during the period of childhood socialization (Farré \& Vella, 2013; Fernández, Fogli, \& Olivetti, 2004; Fortin, 2005; Thornton, Alwin, \& Camburn, 1983; Vella, 1994). These translate to individual work preferences, which in turn have been shown to affect women's labor market outcomes (Fortin, 2005; Gash, 2008; Hakim, 2000; Steiber \& Haas, 2009, 2012; Vella, 1994). Second, while quasi-experimental studies have convincingly shown that parental leave policies (Gangl \& Ziefle, 2015; Kluve \& Tamm, 2012; Lalive \& Zweimüller, 2009; Waldfogel, 1998a) and childcare provision (Baker, Gruber, \& Milligan, 2008; Berlinski \& Galiani, 2007; Cascio, 2009; Havnes \& Mogstad, 2011; Lefebvre \& Merrigan, 2008; Lundin, Mörk, \& Öckert, 2008) do have an effect on motherhood penalties (although these effects seem to depend on the cultural context), empirical evidence on the importance of societal norms is scarce. Ascribing motherhood penalties to cultural differences has thus far mostly been resting on theoretical reasoning and cross-sectional country comparisons (e.g. Boeckmann et al., 2014; Budig et al., 2012), as exogeneous changes in norms are rare and measuring the causal impact of societal norms thus is a challenging endeavor.

We make use of a unique historical setting that allows us to analyze the effects that the societal contexts early in life and at the time of childbirth have on maternal work preferences and labor market outcomes. The division of Germany at the onset of the Cold War 1949 separated the country into the socialist German Democratic Republic (GDR) and the parliamentary democratic Federal Republic of Germany (FRG). The two countries developed fundamentally different norms regarding women's roles and their integration into the labor market as well as different leave policies and childcare institutions (Cooke, 2006; Künzler, Walter, Reichart, \& Pfisster, 2001; Rosenfeld, Trappe, \& Gornick, 2004; Trappe, 1996). After reunification in 1990, Germany's institutional framework of the family was generalized to all of the country (Pfau-Effinger \& Geissler, 2002), aligning parental leave schemes and return policies. While childcare availability was slowly expanded in West Germany, gender egalitarian norms and attitudes towards women's employment until today remain higher in East Germany (Adler \& Brayfield, 1996; Bauernschuster \& Rainer, 2011; Pfau-Effinger \& Geissler, 2002; Rosenfeld et al., 2004). After the fall of the Inner-German border, Germany also experienced an unprecedented rate of mobility from East to West Germany (Fuchs-Schündeln \& Schündeln, 2009). Using this historical setting, we compare work preferences as well as labor force participation, working hours and hourly wages for mothers who were socialized in East Germany and migrated to West Germany after reunification with mothers who stayed in both parts of the country. We are thus able to analyze the influence of exposure to the societal context at the time of childbirth on maternal work preferences and outcomes later in life. Moreover, we are able to assess whether changes in institutions or changes in 
societal norms alter these preferences and outcomes, which allows us to paint a more holistic picture of how the societal context matters for the emergence and persistence of motherhood penalties.

We draw on survey data from the German Socio-Economic Panel (SOEP) which contains a wealth of sociodemographic data and individual work histories. The data are internationally unique in providing not only information on labor market outcomes, but also on work preferences for a large number of mothers who grew up in different regional contexts, experienced vast changes in the institutional setting, and relocated into a context with similar institutions but different societal norms. They thus specifically permit us to observe changes in work preferences dependent on the institutional and normative context. Using an event study design, we are able to show the development in labor force participation, working hours, hourly wages and work preferences. Assessing the discrepancies in preferences and outcomes before and after childbirth, we are moreover able to address to what degree the lack of public childcare institutions or societal norms prevent mothers from fulfilling their work preferences.

Understanding the role of the societal context is of particular importance to understand the origins and persistence of motherhood penalties. Any penalty that affects mothers but does not affect fathers will essentially contribute to gender inequality. The pay gap reduces economic well-being of single mothers and children (England, Bearak, Budig, \& Hodges, 2016), bargaining power (Bittmann, England, Sayer, Folbre, \& Matheson, 2003), and negatively affects life-time earnings and private pension income (Budig \& England, 2001). From a societal point of view, it is thus important to understand the phenomena that facilitate or curb these mechanisms.

\section{Theory and previous findings on the motherhood penalty}

\section{Causality}

Past research largely agrees on the existence of wage penalties for mothers and on the presence of multiple individual and context-level mechanisms (Anderson, Binder, \& Krause, 2002, 2003; Budig \& England, 2001; Cukrowska-Torzewska \& Matysiak, 2020; Gangl \& Ziefle, 2009; Waldfogel, 1997, 1998a, 1998b). Because causality is oftentimes difficult to claim as fertility would need to be randomized, most studies cannot fully preclude selectivity of mothers into lower paid positions before childbirth or a preference for positions with lower pay after childbirth. However, there is a large consensus that the associations are not spurious (Budig \& England, 2001). Some studies use instruments for the number of children such as twin births (Bronars \& Grogger, 1994) or sibling sex mix (Angrist \& Evans, 1998) or use family background characteristics or biological fertility shocks as instruments for motherhood and the timing of birth (Amuedo-Dorantes \& Kimmel, 2005; A. R. Miller, 2009; Neumark $\&$ Korenman, 1994). Other studies use laboratory experiments or audit designs to study the effects of 
motherhood on employment (Correll et al., 2007). These studies generally confirm a causal effect of motherhood on wages.

\section{The motherhood penalty, its components, and contributing factors}

While definitions of motherhood penalties vary across studies, three components generally make up the total wage penalties. First, mothers are less likely to work in the labor market than non-mothers. In 1990, only 40 percent of women with a child under one year were employed (Klerman \& Arleen, 1999). Second, mothers often reduce their working hours after returning to the labor market and are more likely to return working part-time (Budig \& England, 2001; Cohen \& Bianchi, 1999; England, 2005). Third, making up the net penalties, mothers receive lower hourly wages even if they work the same hours and if they had the same experience (Kleven, Landais, \& Søgaard, 2019; Sigle-Rushton \& Waldfogel, 2007).

Each of the three components are affected by a number of influencing factors associated with motherhood. Mothers may reduce their labor force participation and their working hours if they have a preference to allocate more time to domestic and childcare tasks or if they are constrained in investing time in the labor market, e.g. by the absence of institutional support, such as affordable childcare (Gash, 2008; Pfau-Effinger, 1998). Women and mothers in particular do more housework than men and oftentimes have the primary responsibility for children, increasing demands on time and effort at home (Bianchi, Milkie, Sayer, \& Robinson, 2000; Budig \& England, 2001; Gupta, 1999; Harkness \& Waldfogel, 2003; Kühhirt, 2012; Sanchez \& Thomson, 1997; South \& Spitze, 1994), even in cases in which they earn more than men (Bittmann et al., 2003). The resulting child-related career breaks and the reduction in working hours directly contribute to the total motherhood penalty (Waldfogel, 1997), but also translate to lower hourly wages (Anderson et al., 2003; Harkness \& Waldfogel, 2003; Kühhirt \& Ludwig, 2012). According to human capital theory, this is because labor market experience and seniority positively affect wages, through their effects on on-the-job training and productivity (Becker, 1985, 1993; Budig \& England, 2001). Moreover, mothers oftentimes have fewer possibilities to work flexible or overtime hours, which may further decrease productivity (Anderson et al., 2003). Women who intend to be mothers may also invest less in human capital even before childbirth, reducing their productivity (Mincer \& Polachek, 1974). Women who anticipate having children may choose less competitive jobs and or occupations in which their human capital depreciates on a lower level during jobless periods (Harkness \& Waldfogel, 2003; Staff \& Mortimer, 2012).

After childbirth, mothers may select into occupations that require less effort but offer lower pay (Harkness \& Waldfogel, 2003) and they may be restricted in their occupational and career mobility once back in the job (Abendroth, Huffman, \& Treas, 2014; Evertsson \& Duvander, 2011; Kleven, Landais, \& Søgaard, 2019). Mothers may also choose firms that offer flexible hours, childcare availability or demand less travel (Budig \& England, 2001; Kleven, Landais, \& Søgaard, 2019). Such firms oftentimes 
offer less pay as employers can fill lower wage jobs if nonpecuniary amenities are traded off against wages (Budig \& England, 2001; Goldin, 2014; Huffman, King, \& Reichelt, 2017).

Lastly, employers might discriminate and refrain from hiring mothers, place mothers in less rewarding jobs, only offer part-time employment, or grant fewer promotions (Correll et al., 2007; Frodermann \& Müller, 2019; Hipp, 2019). Previous studies have identified manifold reasons: motherhood is a devalued status in the labor market and lower pay for lower perceived status can be regarded as fair (Auspurg, Hinz, \& Sauer, 2017). Moreover, mothers may be perceived as less competent and committed to work (Correll et al., 2007; England, 2005; Ridgeway \& Correll, 2004, 2016) or as less warm or interpersonally hostile if they are successful (Benard \& Correll, 2010). Correll et al. (2007) argue that the normative belief that the "ideal worker" should sacrifice all other concerns for work clashes with the norm that mothers should always be on call for their children (also see Collins, 2019). Because employers anticipate increased demand for flexible working hours and as part-time work is seen as the sensible employment form for mothers (Pfau-Effinger, 1998), employers may only offer part-time employment. Moreover, hiring women as part-time workers may simply be more beneficial to employers (Kjeldstad \& Nymoen, 2012; Künn-Nelen, De Grip, \& Fourage, 2013).

While all of these mechanisms can theoretically contribute to motherhood penalties, individuallevel moderators such as the household composition, marital status (Budig \& England, 2001), education and skill level (Anderson et al., 2002, 2003; England et al., 2016; Wilde, Batchelder, \& Ellwood, 2010), income level (Budig \& Hodges, 2010; Glauber, 2018), race (Glauber, 2007) or the timing of birth (Hotz, Williams McElroy, \& Sanders, 2005; Wilde et al., 2010) can affect the strength of the relationship between motherhood and wages. To what degree and how exactly childbirth affects the motherhood penalty is thus dependent on a large and complex set of contributing factors.

\section{Societal context and its effects on motherhood penalties}

The degree of the motherhood penalty also strongly varies by the regional context (Gangl \& Ziefle, 2009; Harkness \& Waldfogel, 2003; Sigle-Rushton \& Waldfogel, 2007; Stier et al., 2001) and the above mentioned moderators cannot fully explain these differences. Explanations for these variations usually refer either to institutional differences between countries (Harkness \& Waldfogel, 2003; Stier et al., 2001; Uunk, Kalmijn, \& Muffels, 2016), to differences in societal norms or to a combination of both (Boeckmann et al., 2014; Budig et al., 2012). These studies usually refer to direct or indirect effects of the context at the time of motherhood. We argue that the societal context should moreover affect maternal work preferences through socialization during youth and through adult socialization and that past institutions and societal norms should be taken into account when explaining variations in motherhood penalties. 


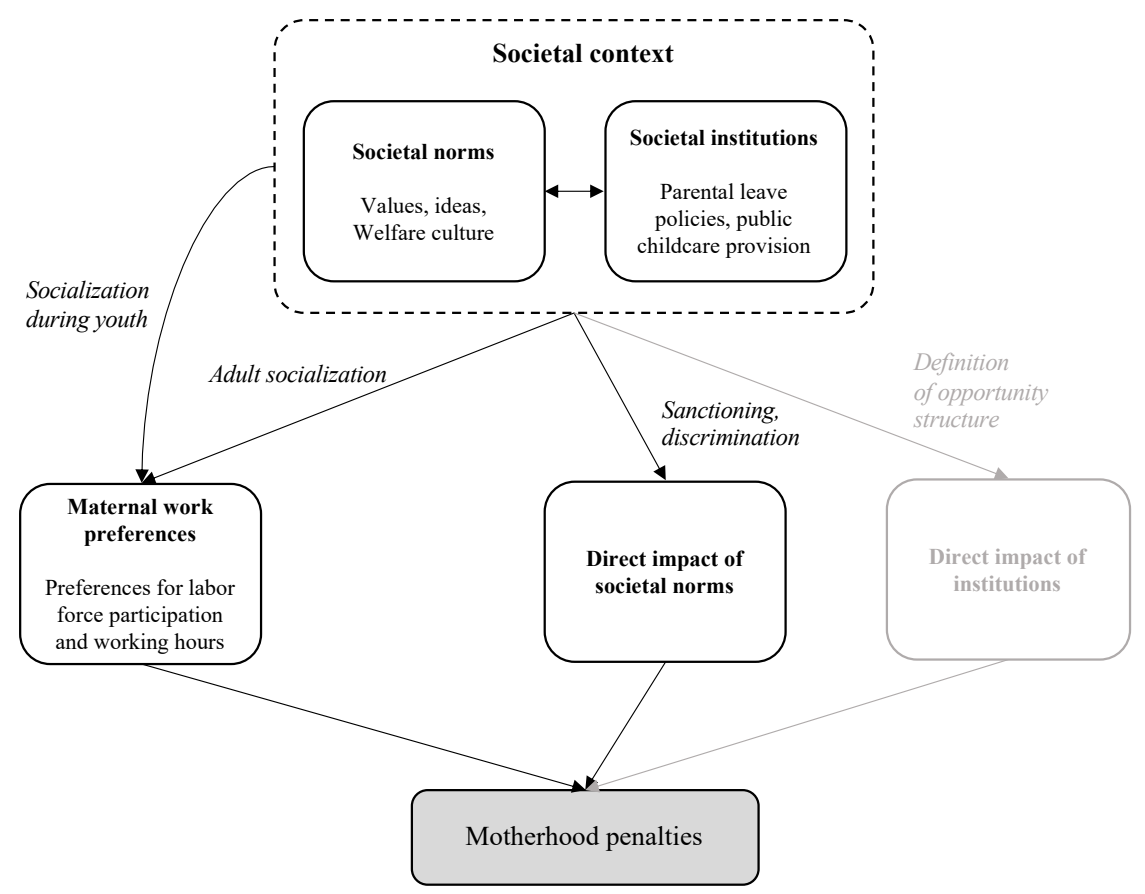

Figure 1 Societal context and its impact on motherhood penalties

Note: Parts in light grey (direct impact of institutions) will not be tested but by construction be excluded and thus controlled for in the empirical analysis.

\section{Direct effects of the societal context: Institutions}

The level of decommodification and the resulting defamiliarization are two aspects of the welfare state that vary considerably between countries, resulting in differences in costs and provision for public subsidized care facilities and parental leave policies (Gangl \& Ziefle, 2015). As Figure 1 shows, these institutions can first and foremost have a direct impact on motherhood penalties through defining mothers' opportunity structure. Most studies on the influence of institutions assume rational actors and predict that mothers act according to how institutions change the cost-benefit structure of labor market decisions. Parental leave policies for example while securing the attachment to the labor market increase the incentive to refrain from the labor market for longer higher costs for public childcare decrease incentives to outsource childcare and return to paid work (Boeckmann et al., 2014; Pettit \& Hook, 2005; Waldfogel, 1998a).

Studies aiming to identify causal effects of parental leave policies through the evaluation of reforms find support for the direct effect in facilitating women's labor force participation but overall uncover differential effects on motherhood penalties (Boeckmann et al., 2014; Gangl \& Ziefle, 2015; Waldfogel, 1998a). Extending parental leave policies has positive effects on mothers' wages in the U.S. and Great Britain (Waldfogel, 1998a). Studies for Germany and Austria find negative effects on employment and earnings in the short-run, but no long-term effects (Gangl \& Ziefle, 2015; Kluve \& Tamm, 2012; Lalive \& Zweimüller, 2009). 
Cross-nationally, higher levels of publicly supported childcare services are positively associated with women's employment (Boeckmann et al., 2014; Pettit \& Hook, 2005; Pettit \& Hook, 2009; Waldfogel, 1998a), and they are thought to decrease the motherhood penalty (Budig et al., 2012). The main arguments are that public childcare allows mothers to engage in paid work and that extensive childcare availability indicates social acceptability of non-maternal childcare (Pettit \& Hook, 2005). Furthermore, childcare costs are associated with women's lower labor market participation (Han \& Waldfogel, 2001). Studies using childcare policy reforms as quasi-natural experiments, however, find partly contradicting effects and cast doubt on a uniform generalizable effect of public childcare availability. Some previous studies find clear positive effects of early childcare availability and its price in Canada and Argentina (Baker et al., 2008; Berlinski \& Galiani, 2007; Lefebvre \& Merrigan, 2008). Others find small or no causal effects on maternal employment in the US, Germany, Sweden, the Netherlands or Norway (Bettendorf, Jongen, \& Muller, 2015; Busse \& Gathmann, 2018; Cascio, 2009; Havnes \& Mogstad, 2011; Lundin et al., 2008; Zoch \& Hondralis, 2017). Huebener, Pape, and Spiess (2019) find that the costs for childcare in Germany reduce working hours, while labor force participation is hardly affected. Similarly, studies evaluating cash-for-care policies in various countries also only find small employment responses to changes in the policies (Gathmann \& Sass, 2018; Naz, 2004; Schøne, 2004). One argument as to why effects are heterogeneous and oftentimes small or non-existent is that childcare expansions mostly crowd out informal care arrangements and thus rather alter the form of childcare but do not affect maternal employment (Havnes \& Mogstad, 2011). Other explanations refer to an interaction of cultural norms and policies, pointing out that parental leaves and public childcare are associated with higher earnings for mothers when cultural support for maternal employment is high (Budig et al., 2012).

\section{Direct effects of the societal context: Norms and values}

A second strain of literature refers to cross-country differences in cultural values, working norms, and preferences to help explain the variation in motherhood penalties and its mechanisms. As Pfau-Effinger (1998) argues, it is "more possible to explain cross-national differences in the extent and forms in which women are integrated into the labour market [...] if these are placed in the context of gender arrangements", mainly referring to the cultural ideals about the gendered division of labor. Societal norms and expectations have been shown to shape mothers' employment and earnings as well as the gendered division of household labor (Budig et al., 2012; Cooke, 2006; Kremer, 2007; PfauEffinger, 2004; Pfau-Effinger, 1998; van der Lippe et al., 2011) and these societal norms differ strongly by country (Cooke, 2006).

Societal norms may directly affect labor market outcomes through social sanctioning (Uunk, 2015). Being in a context with more traditional norms, women who would like to work might receive no help in their search or employers might not consider mothers or only offer part-time employment. 
Accordingly, Correll et al. (2007) experimentally show that employers discriminate against mothers because if the cultural understandings of the roles of motherhood and ideal workers are in tension. Accordingly, discrimination is more likely to occur in settings with more traditional gender norms and family role expectations and less so in contexts with egalitarian attitudes towards gender and family responsibilities (Hipp, 2019). However, even in a more egalitarian context, women might face informal sanctions from the community (Uunk, 2015). Using longitudinal data and a fixed-effects design, Uunk and Lersch (2019), however, show that county-level gender role attitudes have no effect on women's labor market outcomes, net of their individual gender roles. At least within-country variations in gender roles thus do seem to directly prevent women from fulfilling their work preferences.

\section{Interactions between norms and institutions}

Norms and institutions are usually closely aligned and interdependent. The direct effects of norms and institutions might thus reinforce one another. A large body of literature recognizes the important influence of gender ideologies on welfare state policies (Kremer, 2006, 2007; Lewis, 1992; Orloff, 1996). Kremer (2006) for example shows how the Flemish women's movement successfully combated the full-time motherhood ideal and helped establish high levels of childcare provision. The effects of societal norms on motherhood penalties via their effects on institutions reflect the idea that the latter can be understood as "systems of established and prevalent social rules that structure social interactions" (Hodgson, 2016). Likewise, institutional changes can reshape societal norms and beliefs (Himmelweit \& Sigala, 2004). For example, childcare expansion has been associated with moderate changes towards more egalitarian gender norms (Zoch \& Schober, 2018).

While theoretically, societal norms and institutions should both play a distinct role, empirically disentangling the effects of institutions and societal norms is not straightforward. First, cross-sectional country comparisons are usually not able to uncover what part of motherhood penalty is due to differences in institutions, such as leave policies or childcare availability and what part is due to partially unobservable cultural differences. This is, because such studies cannot possibly take into account all the differences between countries and institutional and cultural settings are oftentimes aligned. Second, as previously mentioned, researchers often face the problem of feedback effects between norms and institutions. While previous theories stress the importance of culture and norms, the question whether or not there are autonomous effects of societal norms on motherhood penalties, net of their effect on institutions, thus largely remains unanswered.

\section{Indirect effects of the societal context: Modeling maternal work preferences}

On a theoretical level, the direct effects of the societal context on motherhood penalties should mainly be mediated by their defining effects on the opportunity structure and the costs and benefits associated with mothers' employment choices. The context should, however, also have an indirect 
impact on mothers' labor market outcomes. Societal norms and values are - to a degree - mirrored in mothers' attitudes and work preferences. As the theory of planned behavior states, attitudes can predict intentions to perform behavior and account for substantial variance in actual behavior (Ajzen, 1991). Accordingly, preference type theories assert that women's gender role attitudes and 'lifestyle preferences' explain their social and economic outcomes, emphasizing the growing role of individual agency (Gash, 2008; Hakim, 2000). Previous studies show that women's attitudes and work preferences affect labor market participation, working hours, the time out of the labor market and wages childcare (Fortin, 2005; Steiber \& Haas, 2012; Vella, 1994). More specifically focusing on mothers, Steiber and Haas (2009) find that attitudes are strongly correlated with their paid work involvement. Likewise, institutions may affect mothers' preference formation, because of contextualized role exposure and norm setting. As Gangl and Ziefle (2015) show, reforms in parental leave policies have led to feedback effects on women's subjective work commitment.

But how and when should societal norms and institutions shape gender attitudes and thus maternal work preferences? Many authors have found that gender roles and female attitudes towards working women and household division of labor are developed in youth through socialization and the influence of parental attitudes, their education and their division of labor (Farré \& Vella, 2013; Fernández et al., 2004; Fortin, 2005; Thornton et al., 1983; Vella, 1994). As both parental behavior and parental attitudes are important for gender-role transmission, established gender norms may shape gender attitudes early in life (Platt \& Polavieja, 2016). These attitudes are then oftentimes argued to be stable over time (Gash, 2008). Women's (and their partner's) preferences regarding maternal labor market participation, working hours and the division of household work may thus affect labor market outcomes much later.

From a theoretical point of view, however, it is yet unclear if these maternal work preferences are truly stable or if they are malleable and adapt to the prevalent societal norms when these change. Changes in norms usually are slow processes and occur across cohorts, but migration can abruptly alter the normative context. Studies on the adaption of attitudes oftentimes refer to adult socialization, lifelong openness, or the importance of place, and show that attitudes partially adapt to new regional contexts (Carter \& Carter, 2014; Glaser \& Gilens, 1997; S. D. Miller \& Sears, 1986; Tyler \& Schuller, 1991). Empirical studies focusing on gender attitudes of immigrants in the US and Europe indicate that exposure to the prevalent values in the host society values induces some acculturation and re-negotiation of gender roles (Dion \& Dion, 2001; Leaper \& Valin, 1996; Norris \& Inglehart, 2012; Röder \& Mühlau, 2014). Other studies, however, indicate that the effect of a change in the societal context on maternal work preferences might not be straightforward. First, the disruptive effects of migration might lead to rigid and idealized gender ideologies while only some aspects of the dominant culture may be selectively adopted (Parrado \& Flippen, 2005). Second, individual gender roles oftentimes change very slowly (Su, Richardson, \& Wang, 2010). As childbirth usually occurs in the first half of women's lives, changes in 
the normative context might not yet translate to maternal work preferences and outcomes. It is thus yet unclear if societal norms shape stable maternal work preferences early in women's lives or if they are malleable when changing into another normative context.

At this stage it is thus not only empirically unclear if societal norms have a direct effect on motherhood penalties, but also unanswered if the societal context has long- and/or short-term effects on mothers' employment outcomes by shaping their work preferences.

\section{German division, reunification, and women's working norms}

To analyze the various effects of the societal context on motherhood penalties, we make use of a unique historical setting. Germany's division and reunification 40 years later, and the subsequent mobility between East and West Germany allows us to observe women, who have been exposed to different societal contexts during their childhood socialization, experienced an alignment of their institutional framework, and became mothers in settings in which societal norms either mirror or stand in contrast to the norms and values of their childhood.

At the onset of the Cold War in 1949, Germany was divided into two countries: The German Democratic Republic (GDR), established in a Soviet zone in East Germany, and the Federal Republic of Germany (FRG), which was established in three western zones. During the divided years, East and West Germany developed remarkably different norms regarding women's role in employment and caregiving as well as vastly different institutional settings.

The GDR followed a state socialist system, which entailed a centrally planned economy and socialist labor and family policies (Rosenfeld et al., 2004). During the divided years, East Germany needed both, men and women, as paid workers and thus strongly supported women's employment (Cooke, 2006). The result was a dual breadwinner / state-carer model in which motherhood and fulltime paid work as well as state control of children's socialization and education was the norm. The role of the housewife was culturally devalued by defaming it publicly, but the wage structure also oftentimes simply required both parents to participate in the labor market (Pfau-Effinger \& Geissler, 2002). While gender equality was one of the main goals of socialist policies, East Germany failed to achieve full gender parity in earnings and division of labor (Rosenfeld et al., 2004). Nonetheless, compared to other European countries, labor market participation and working hours for women were remarkably high. The standard work week in the GDR was 43.75 hours. Part-time work was rather performed by older women and with long weekly hours, while for mothers, part-time work was considered exceptional (Rosenfeld et al., 2004). Especially later in the GDR's history, this cultural setting was accompanied by a large public childcare system (again exemplifying the interrelation between gender ideology and institutional policies) (Künzler et al., 2001; Trappe, 1996) 
In contrast, the FRG established a multiparty parliament with a market economy and a socially conservative welfare state. West German policy favored a male breadwinner model, deterring women, especially mothers, from paid work and relegating them to unpaid housework (Cooke, 2006; Rosenfeld et al., 2004; Sainsbury, 1999). The consequences were considerably lower labor force participation and lower working hours among women in the FRG. A large part of the difference to East Germany's rates in labor force participation can be attributed to differences among mothers. In the GDR, participation rates varied little by marital and parenting status, whereas in the FDR most mothers with children dropped out of the labor force or heavily reduced their working hours. (Rosenfeld et al., 2004). Parttime work was particularly encouraged through state policies and most female part-time workers were employed for fewer than 20 hours per week (Künzler et al., 2001; Rosenfeld et al., 2004). The increasing shift to female part-time work modernized the male breadwinner model, but also enabled its survival (Pfau-Effinger, 1993). In West Germany, the cultural setting was - and to a degree still is - accompanied by a lack of adequate daycare for children as well as expansive leave policies and a tax system that rewards family decisions in favor of the male breadwinner model (Aisenbrey, Evertsson, \& Grunow, 2009). It is often argued that the substantial shortage of publicly and privately funded childcare in former West Germany required one parent to exit the labor force and provide at-home care (Pettit \& Hook, 2005).

In October 1990, following the collapse of state socialism in Eastern Europe and the Soviet Union, East and West Germany reunified. East Germany voted to accede to the Federal Republic of Germany, resulting in an expansion of the initial 10 states to 16. As Rosenfeld et al. (2004) put it, these circumstances provided a "natural experiment concerning the effect of institutions, policies and gender norms on work".

The transformation of East German institutions and employment structures largely resulted in convergence of gender-related policies with one exception: Public supply of childcare remained higher in East Germany (Rosenfeld et al., 2004). ${ }^{1}$ While the institutional policies aligned with this one exception, social practices and gender roles have remained substantially different until this day (Adler \& Brayfield, 1996; Pfau-Effinger \& Geissler, 2002) and in part even increased (Bauernschuster \& Rainer, 2011). The vast majority of East German women prefer to be employed full-time (85 percent) instead of being a housewife or being employed part-time (Pfau-Effinger \& Geissler, 2002). Accordingly, Table 1 shows that attitudes towards mothers' work arrangements are still significantly more egalitarian amongst residents in East Germany. Mirroring attitudinal differences, the gender gap in labor force participation is still considerably smaller in East Germany, and the female participation

\footnotetext{
${ }^{1}$ The share of public sector jobs also remained higher in East Germany, which however would suggest larger motherhood penalties because of a higher share of women in the public sector, higher prevalence of part-time work, and lower wages. We thus assume that the differences in East-West motherhood penalties ascribed to cultural variation are an estimate at the lower bound.
} 
rate exceeds that reported in the West by 10 percentage points. Likewise, the division of labor is more egalitarian in East Germany (Cooke, 2006). Differences in mothers' labor market outcomes are quite similar and in 2000, only 15 percent of women with young children were employed in West Germany, compared to 30 percent of women in East Germany (Holst \& Schupp, 2001).

Table 1: Gender attitudes in East and West Germany 2016

\begin{tabular}{llll} 
& West & East & Difference \\
\hline $\begin{array}{l}\text { Women with small children } \\
\text { should not work }\end{array}$ & 2.40 & 1.90 & $-0.501^{* * *}$ \\
$\begin{array}{l}\text { A working woman can be a } \\
\text { good mother }\end{array}$ & 2.77 & 3.36 & $0.594^{* * *}$ \\
$\begin{array}{l}\text { Parents should work full- } \\
\text { time and share household }\end{array}$ & 2.58 & 3.34 & $0.764 * * *$ \\
work & & & \\
\hline
\end{tabular}

All items are surveyed on a scale from 1 (completely disagree) to 4 (fully agree). Source: Allbus 2016, own calculations using cross-sectional survey weights.

These findings speak in favor of rather long-term effects of the societal context on individual beliefs and attitudes. Accordingly, previous research on the persistent (although slowly converging) East-West differences in labor market outcomes refers to cultural explanations, emphasizing how ideas, preferences and social norms shape gendered outcomes. These studies argue that families tend to arrange their lives in certain ways in part because that is what has been done before, thus emphasizing inertia in societal norms (Rosenfeld et al., 2004).

In the years following reunification, Germany observed a tremendous amount of East to West migration, as 2.45 million or about 17 percent of East Germany's population migrated to West Germany (Fuchs-Schündeln \& Schündeln, 2009). Source income and unemployment during and after East Germany's transformation period played a significant role in the decision to move to West Germany, but social ties into the West and psychological factors may have also contributed. Notably, FuchsSchündeln and Schündeln (2009) find no clear differences between men's and women's migration probabilities.

The persistence in attitudinal differences toward maternal employment in East and West Germany, the large alignment in institutional settings, and East-West mobility after reunification provide us with a unique setting that allows us to assess long- and short-term effects of the societal context on mothers' employment preferences and their labor market outcomes. The setting also enables us to separate the effects of societal norms from institutional influences, as a significant number of women who later became mothers moved to an institutionally similar setting with different societal norms. We are moreover able to assess the effects of public childcare provision on motherhood penalties as the West German provision was significantly expanded after reunification. 


\section{Hypotheses}

How and when should the societal context affect maternal work preferences regarding labor force participation and working hours for different groups in East and West Germany? How should these preferences affect labor market outcomes? And how should societal norms directly affect motherhood penalties in East and West Germany?

Maternal work preferences: As outlined above, we assume that the societal context shapes attitudes and maternal work preferences early in life. It may also affect preferences at the time of childbirth and -care. Women who grew up in East Germany before reunification, should have developed more egalitarian work preferences with a preference for more working hours compared to mothers, who grew up in West Germany. If the adult societal context affects maternal work preferences, East German mothers should adapt their preferences more towards those of West German mothers after reunification. Women who migrate from East to West and thus also change their normative context should adapt their work preferences to those of West German women even more. Especially after childbirth, preferences for labor force participation and working hours should decrease to a stronger degree compared to mothers in East Germany. If, on the other hand, attitudes and maternal work preferences are stable and unaffected by changes in the normative context, East German mothers' work preferences should consistently be higher than those of West German mothers, even after relocating to West Germany. Depending on how quickly attitudes are adapting and preferences are being formed, we would expect preferences in-between those of East and West German mothers. Theoretically, preferences might also adapt according to structural restrictions rather than societal norms. Movers from East to West Germany, however, experience a more favorable labor market with higher demand and a similar institutional framework with the exception of lower public childcare provision. If the latter has an effect, we would assume that East German mothers' preferences in West Germany adapt more before childcare expansion.

Maternal labor market outcomes: Maternal work preferences should directly affect probabilities for labor market participation and affect working hours after childbirth. Although most likely not having a preference for lower hourly wages, part-time employment may also be associated with lower wages. We thus assume maternal work preferences to translate to larger motherhood penalties in West Germany. Societal norms and institutions in West Germany should align in the long run and we thus do not assume to find consistent mismatches between preferences and outcomes among West German mothers. Reunification introduced more generous leave policies in East Germany, which might affect mothers' preferences in East Germany, but would not prevent mothers' from fulfilling their more egalitarian preferences. While the more difficult employment situation in East Germany should have an impact on whether or not work preferences can be fulfilled, such restrictions should not apply to mothers only, thus affecting mismatches before and after childbirth, but not motherhood penalties. Mothers who 
move from East to West Germany, however, might not be able to fulfill their preferences, if these do not adapt to West German preferences and if they face larger structural restrictions through lower levels of childcare provision. Maternal labor market outcomes should then mirror those of West German mothers before childcare expansion and approach outcomes of mothers in East Germany after the expansion.

Lastly, societal norms may have direct effects on motherhood penalties. The local community might indirectly or directly sanction mothers who are not adhering to local social norms. Employers' preferences in East and West Germany_assuming that the majority of decision makers in companies were socialized in the same region - should broadly align with local societal norms but stand in contrast to the preferences of movers, potentially amplifying discrimination. Preferences and outcomes of mothers who move from East to West, who prefer to work more than what is culturally considered the norm, should thus diverge and hourly wages should consequentially be more negatively affected in West Germany.

\section{Data and descriptives}

We use data from the German Socio Economic Panel (SOEP; v33), a nationally representative longitudinal study of East and West Germany (Wagner, Frick, \& Schupp, 2007). We draw on the 19912016 waves, because data before reunification is limited to West Germany. The SOEP is a unique data source that, besides standard labor market outcomes and current working hours, contains measures on employment preferences and preferred working hours.

Our key independent variable is the time before and after the birth of the first child, measured in years. We identify the birth of a child based on the biographical information provided in the data. For each individual, the SOEP survey contains information on the birth of children including the year and month of birth. This allows us to identify long-run effects of childbirth, even if the respondent did not take part in the survey in the respective year. For each respondent, we calculate the difference in years between the survey year and the year of birth. ${ }^{2}$ We follow the trajectories of mothers (and fathers for the purpose of comparison) in our sample up to 5 years prior and 15 years after childbirth.

The SOEP survey data enable us to analyze the development of work preferences and different labor market outcomes before and after childbirth for mothers who grew up in East and West Germany and thus were exposed to different societal contexts. We investigate a number of outcomes, namely (i) the total parenthood penalty in terms of monthly wages, including zeroes for individuals who are not working, (ii) the labor force participation (defined as working in a regular job, excluding marginal employment), (iii) working hours, conditional on labor force participation (iv) hourly gross wages,

\footnotetext{
${ }^{2}$ If, for example, the first birth takes place in May 2001 and the survey in July 2001, this survey wave in the data would is coded as $t=0$.
} 
conditional on being employed, (v) preference for labor force participation, and (vi) preferred weekly working hours. Preference for labor force participation, is based on the question whether a respondent would like to work now. As this survey item is conditional on not working, we use preferred working hours to measure the preference for not working if the respondent is currently being employed. We compare preferences for labor market participation and working hours with the realized outcomes to analyze whether preferences are fulfilled or not.

The data also contains information on the federal state and the broader NUTS2-region of the place of living as well as information on whether schooling was completed in East or West Germany. For our analytical sample, we only select mothers with a partner, who grew up in the same region (East/West) so that the societal context during youth and adolescence is kept constant across all relationships. East and West German mothers (and their partners) need to have completed their schooling in East or West Germany respectively. Movers are defined as having received schooling in East Germany and living in a West German federal state at the time of first childbirth. ${ }^{3}$ To check for the robustness of our results, we also compare East to West movers to movers within East and West Germany. We define East to East (West to West) movers as couples who completed their education in East (West) Germany and moved between NUTS2-regions in East (West) Germany prior to giving birth. While reducing the sample size, this additional restriction leads to more comparable samples of movers and thus tackles several selection issues, such as moving as a reaction to childbirth or withdrawal from the labor market because of lacking family support.

We only include a limited set of control variables in our analysis to identify the total effect of childbirth on the previously mentioned outcomes as we are not interested in identifying all possible mechanisms but the effect of the societal context on work preferences and labor market outcomes. These controls are indicator-variables for the age at the time of the survey, survey year dummies and years of schooling. Table A1 shows sample descriptives for women for the different groups of interest, including the number of children 10 years after giving birth as well as the average working hours within 5 years prior to their first birth. The table does not indicate substantial differences between the groups, supporting previous findings that movers to West Germany were not particularly selective.

\section{Empirical Strategy}

Our empirical strategy follows an event study methodology (for another application of this method in regards to motherhood penalties, see Kleven, Landais, \& Søgaard, 2019). To investigate the consequences of becoming mothers (and fathers for comparative purposes) over time, we estimate the following regression model:

\footnotetext{
${ }^{3}$ We exclude single mothers and mothers who received their schooling degree in West Germany and moved to East Germany as well as mothers whose partners received a schooling degree in the other region.
} 


$$
Y_{i t}=\beta_{0}+\beta_{1} \gamma_{i t}+\beta_{2} \text { syear }_{t}+\beta_{3} \text { age }_{i t}+\beta_{4} \text { educyrs }_{i t}+u_{i t}
$$

Where $Y_{i t}$ is an outcome of interest for person $i$ in time period $t . \gamma_{i t}$ is a set of indicator variables that depicts the time around birth, syear ${ }_{t}$ a set of survey year dummies, age $_{i t}$ is a set of respondent age dummies and educyrs ${ }_{i t}$ is the years of schooling. We do not control for any other observable characteristics to obtain the total effect of childbirth on the various outcomes. We restrict our observation periods to five years prior and 15 years after birth of the first child. Controlling for age and survey year fixed effects allows us to account for yearly variation as well as age effects without making any assumption concerning the functional form of the respective correlations. Because we use panel data, we use cluster-robust standard errors (on the respondent's level) to account for the structure of our data. ${ }^{4}$

The underlying assumption for the event study approach to be valid is that the event, i.e. childbirth, is not determined by the outcome variable, i.e. the labor market outcomes of interest, conditional on the set of covariates (Kleven, Landais, \& Søgaard, 2019, Appendix B). We also show the trajectories of the outcomes prior to giving birth to test this assumption. If the assumption is violated, we should already see a trend change in the outcome of interest prior to pregnancy. ${ }^{5}$

The omitted category for the dummy variables measuring the time to childbirth is -1 . i.e., all coefficient estimates plotted in the results are the difference in the outcome of interest compared to one year before childbirth for each group separately

\section{Results: How the societal contexts affect motherhood penalties in East and West}

\section{Germany}

How and when do societal contexts shape motherhood penalties? To answer this question, we make use of Germany's division into East and West Germany and its reunification. The alignment of the institutional framework, the consistency in gender attitudes in East and West Germany, and the subsequent mobility from East to West Germany lets us assess the long- and short-term effects of the

\footnotetext{
${ }^{4}$ Unlike Kleven, Landais, Posch, Steinhauer, and Zweimüller (2019); Kleven, Landais, and Søgaard (2019), we do not use a balanced panel in our analysis due to power issues. However, our overall sample means for maternal age at birth as well as the number of children at $\mathrm{t}=10$ for the overall sample are, at one decimal point, equal to the values reported for the SOEP by Kleven, Landais, Posch, et al. (2019, Table A.1). We are thus confident that using an unbalanced panel does not lead to a systematic sample selection bias.

${ }^{5}$ Kleven, Landais, and Søgaard (2019) also present different robustness checks concerning this assumption in online Appendix B to their paper, for example using a difference-in-differences setting in which they compare mothers to women never giving birth or using an instrumental variable approach. Their results never differ significantly from the baseline event study. Thus, the identifying assumptions seem to hold.
} 
societal context through shaping maternal work preferences and allows us to disentangle the direct impact of societal norms from institutional policies.

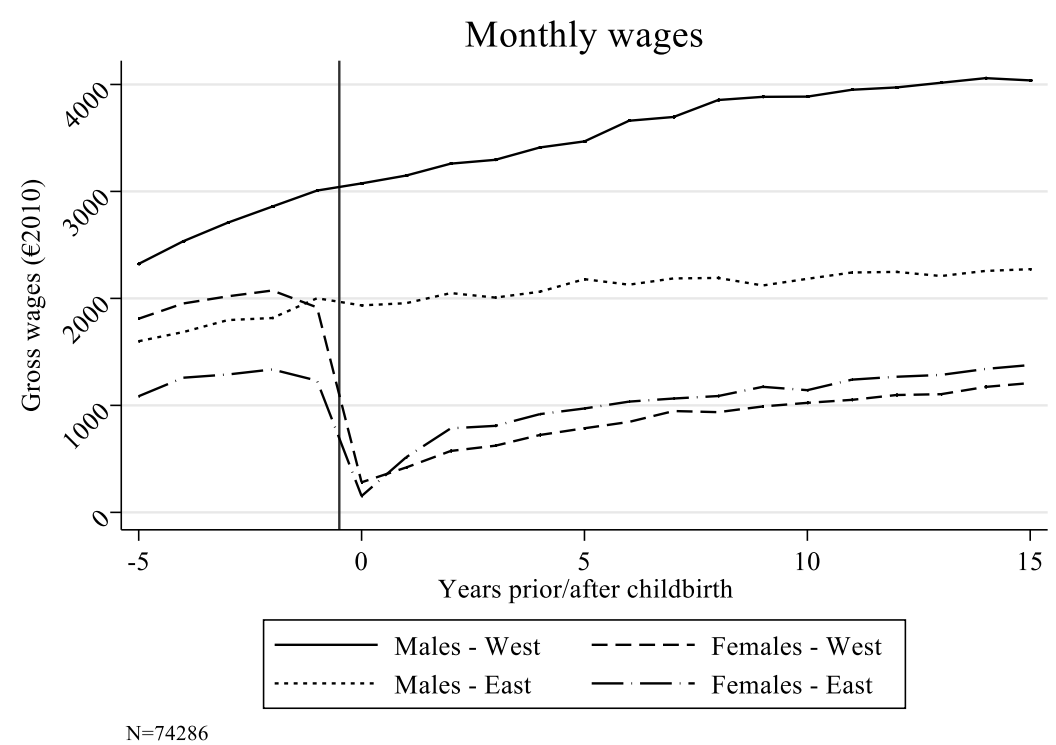

Figure 2: Monthly wages for men and women before and after childbirth in East and West Germany

Before explicitly focusing on the role of the societal context, we briefly describe how motherhood penalties in Germany develop after childbirth. To that end, Figure 2 provides the data on women's and men's average gross wages before and after childbirth separately for East and West Germany. The graph plots wages without controlling for additional variables. It thus shows the total penalties for women and men who become parents. Because non-parents are ignored, the part of the motherhood penalty that emerges due to the selection of mothers into lower-paying mother-friendly occupations and positions pre-birth is already controlled for (for a discussion of this mechanism, see Harkness \& Waldfogel, 2003; Staff \& Mortimer, 2012). While wages and wage trajectories for men in both East and West Germany do not seem to be affected by childbirth, wages for women in both parts of the country drop substantially from a monthly average of around 1,900 and 1,200 Euros one year before childbirth to about 280 and 150 Euros the year after childbirth. As the wage level is substantially higher in West Germany, mothers' wage trajectories reveal a substantially larger motherhood penalty in West Germany. The wages only slowly recover and while mothers' wages in East Germany reach the pre-birth wage level approximately 15 years after childbirth, average wages for West German mothers remain substantially lower compared to pre-birth levels. 

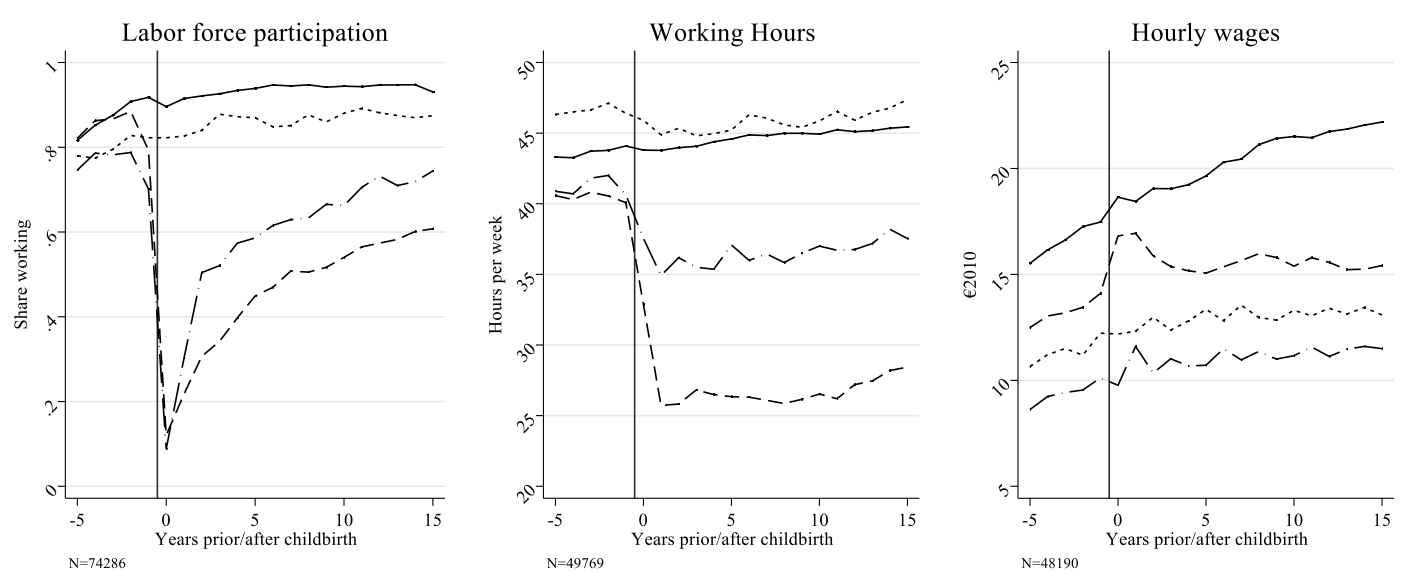

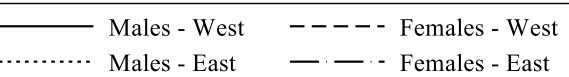

Figure 3: Labor market outcomes for men and women before and after childbirth in East and West Germany

Note: Sample size differs across measurements because labor force participation includes unemployed, while all other measures only apply to employed. Remaining differences result from missing values in wage data.

Figure 3 splits the motherhood penalty up into its three components: labor force participation, working hours, and hourly wages. It descriptively shows that lower wages and the slowed wage growth after childbirth are mainly due to mothers' retraction from the labor market and a reduction in working hours. Both factors also seem to drive East-West differences. While labor force participation in East Germany in general is slightly lower, employment rates for men and women in both regions are almost identical the year before childbirth, reaching around 80 to 90 percent. Unsurprisingly, given generous maternity leave policies, mothers' labor force participation in both parts of the country drops to about 15 percent within one year after childbirth, while fathers' employment rates remain stable. Mothers in East Germany, however, return remarkably quicker to the labor market and do so to a larger degree, compared to mothers in West Germany. Average working hours show an even greater disparity, dropping from more than 40 hours per week to around 35 in East Germany and 25 in West Germany the years after childbirth. Hourly wages, while generally being lower for women, do not seem to be immediately affected by childbirth, which may reflect the guaranteed right to return to the same position after maternity leave. Gender pay gaps nonetheless increase over time, because mothers' wages do not grow as much as West German men's wages. The stalled wage growth potentially indicates negative downstream effects emerging from lower pay in mother-friendly positions, or discrimination, especially for mothers in West Germany. Furthermore, part-time work is associated with job penalties such as lower pay, lower probabilities for promotions and downward occupational mobility, potentially further contributing to gaps in hourly wages, most visible in West Germany (Hirsch, 2005; Perry, 1990; Webber \& Williams, 2008). 

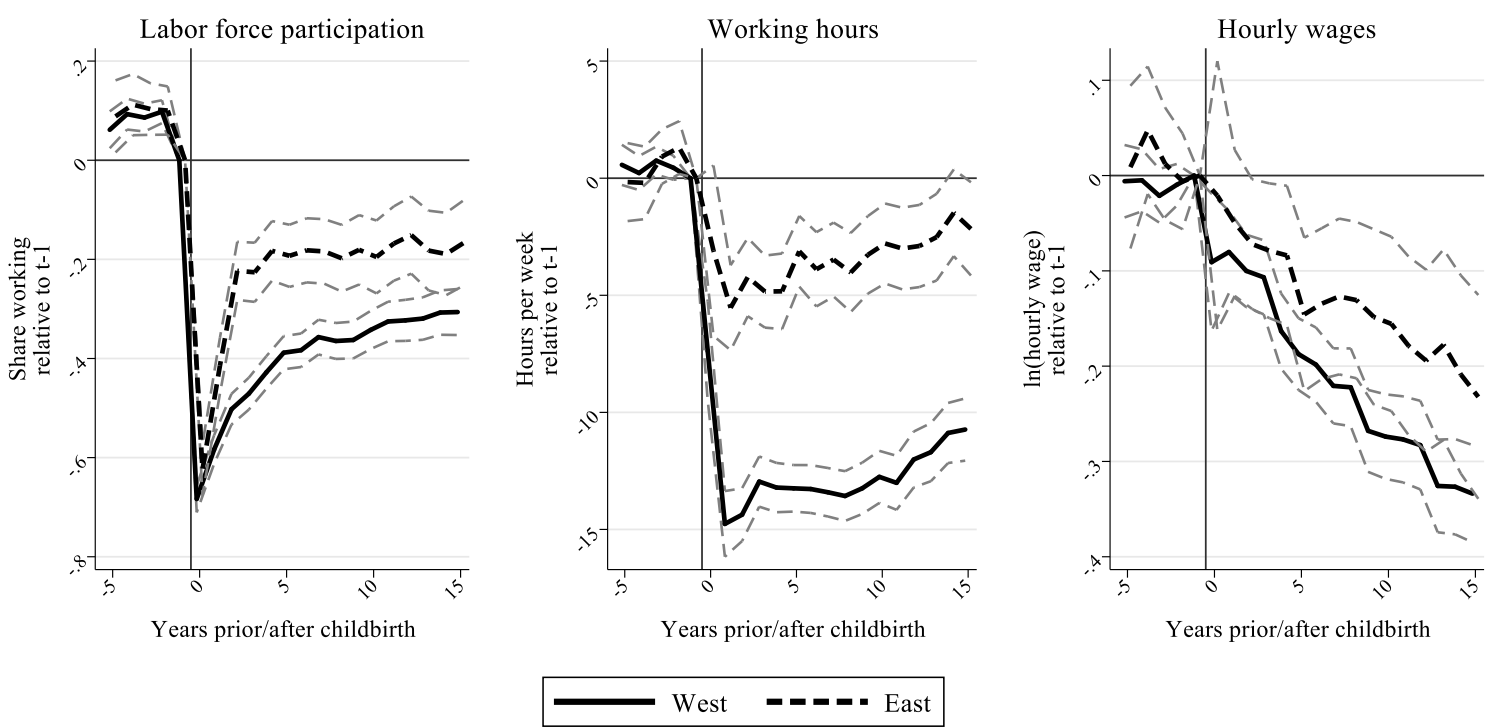

Figure 4: OLS-results for labor market outcomes on time before and after childbirth for mothers in East and West Germany with 95\%-CIs

Using linear regressions with event dummies and adding control variables confirms that the decline in labor force participation and the reduction in working hours are statistically significant (see Figure 4 and Appendix Tab. A2 for coefficient estimates). ${ }^{6}$ Controlling for age effects, hourly wages of mothers even develop negatively, confirming that these are lower compared to what similarly aged women without children would earn. With the exception of hourly wages, these developments are also significantly different for mothers in East and West Germany, which provides a first indication of the importance of the societal context. West Germany's modernized male breadwinner model encourages lower labor force participation and female part-time work, while norms regarding maternal employment in East Germany's promote a more egalitarian division of work. At this stage it is yet unclear though, if the societal context has long- or short-term effects and if the differences stem from differences in maternal work preferences or direct effects of different societal norms.

We argue that the societal context shapes maternal work preferences during the period of socialization and that these preferences translate to labor market outcomes if there are no additional restrictions. Figure 5 shows mothers' preferences for labor force participation (meaning either being employed and not wanting to drop out of the labor market or wishing to return to the labor market) and their preference for working hours in East and West Germany. As hypothesized, the work preferences significantly differ between the two regions. While the preferences for labor force participation drop by about 70 percent during the year of childbirth, they quickly rise again for mothers in East Germany. Mothers in West Germany want to return to the labor market later and to a lower degree. Preferences

\footnotetext{
${ }^{6}$ See Appendix Fig. A1 and Tab. A4 for estimates on the total motherhood penalties.
} 
for working hours drop by two hours for mothers in East Germany and 10 for mothers in West Germany and both preferences remain relatively stable over the subsequent years. The stark differences in preferences suggest a strong effect of the societal context-present or past. While we assume that preferences are shaped by norms and institutions, it is also possible that maternal work preferences partially adapt to the economic conditions. Due to the disadvantaged economic situation in East Germany, mothers may have needed to return to the labor market more quickly and work more hours if the household income was not sufficient, which could be reflected in their work preferences. Additional analyses, however, show no substantial differences between preferences of mothers whose partners earnings lie above or below the regional median wage (see Appendix Figure A.3) and between preferences in times of high or low unemployment (see Appendix Figure A.4).

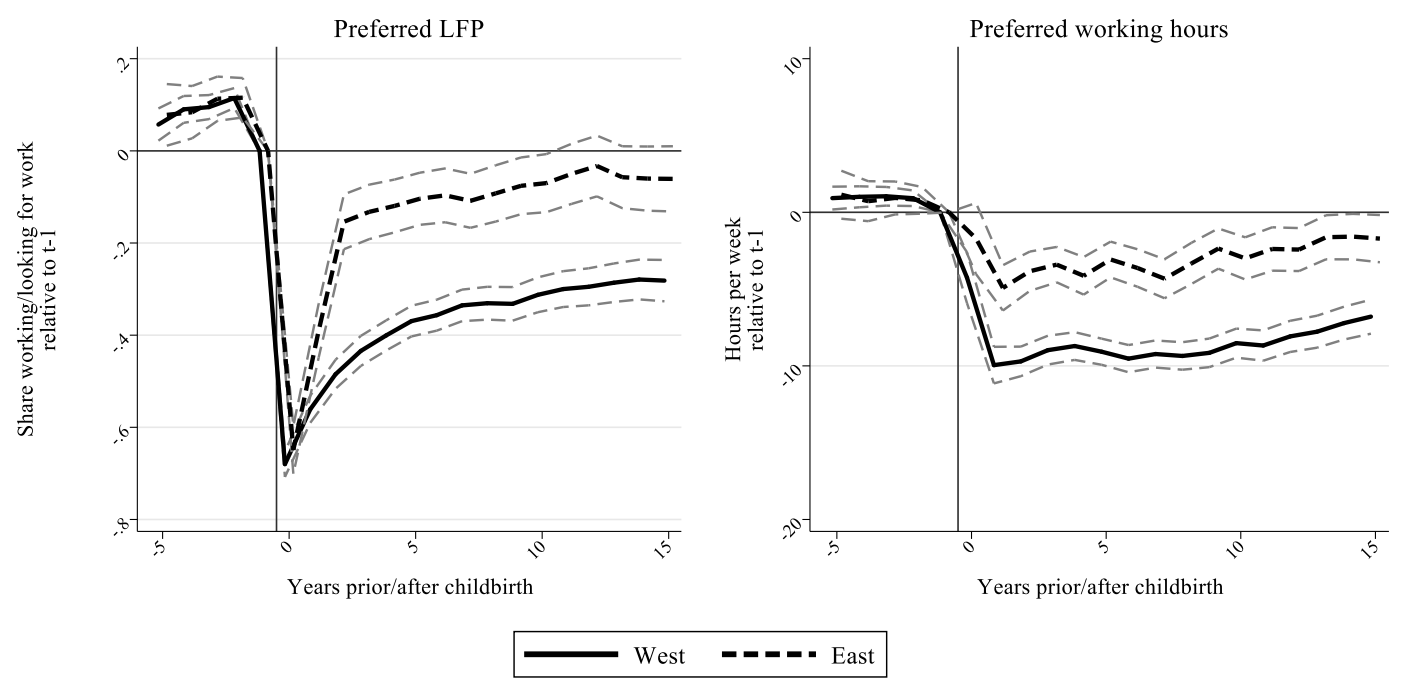

Figure 5: OLS-results for work preferences on time before and after childbirth for mothers in East and West Germany with 95\%-CIs

To test whether maternal work preferences are shaped early in life and whether they remain stable or adapt to the societal context at an adult age, we will next assess how work preferences for East German mothers react to changes in the institutional and normative context. We first compare preferences for mothers in East Germany, who had their first child before reunification with mothers who had their first child after reunification, shown in Figure 6. As we do not have data on East Germany before reunification, we compare preferences three years after childbirth and later. Reunification resulted in the convergence of gender-related policies with the exception of public supply of childcare. We exclude the years 1989 and 1990 in order to have a clear change from GDR regulations to the new institutional framework. The figure shows that preferred labor force participation and working hours for women whose child was born before reunification do not significantly differ from women's preferences whose child was born after reunification. We cannot preclude that the institutional changes had effects on return preferences up to three years after childbirth. Nonetheless, they do not seem to have significantly altered preferences in the longer run. 


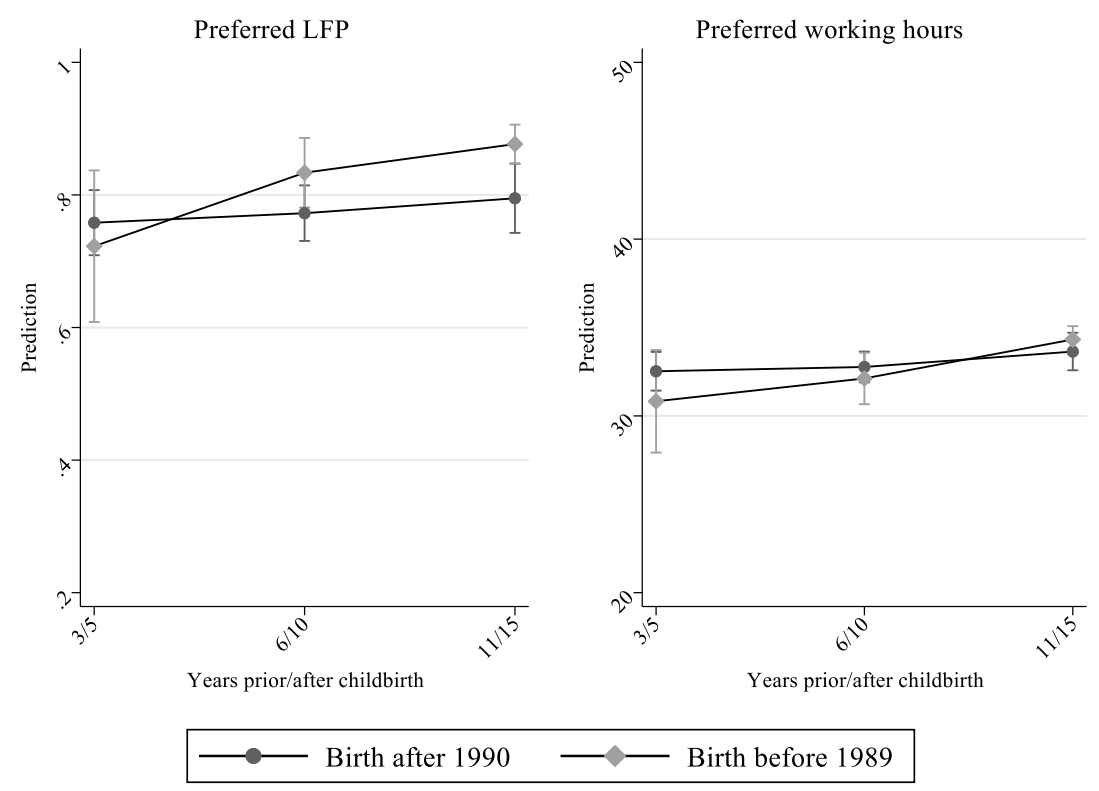

Figure 6: Differences in preferred labor force participation and working hours for mothers in East Germany with childbirth before and after reunification; predicted values with 95\%-CIs

Second, we assess, if changes in the normative context and changes in childcare provision alter maternal work preferences or if maternal work preferences are mainly shaped by the societal context through socialization during youth and adolescence. Figure 7 shows preferred labor force participation and preferred working hours for mothers who move from East to West Germany and mothers who stayed in East Germany or West Germany (see Appendix Tab A.3 for predicted values with standard errors). ${ }^{7}$ It also shows mothers' realized labor market outcomes and the differences between preferences and outcomes, which lets us analyze the direct effects of societal norms in the next step. We define movers as women who received their schooling degree in East Germany before reunification, together with their partner who also received a schooling degree in East Germany moved to West Germany, and subsequently became mothers. These mothers were socialized in a context with more egalitarian gender norms. Moving to West Germany, however, places them in a context with on average more traditional gender norms.

\footnotetext{
${ }^{7}$ As a robustness check, we compare mothers who move from East to West Germany with mothers who move within the respective regions (see Appendix Fig. A2 and Tab. A5). Comparing cross-region movers with regioninternal movers minimizes the risk that differences in outcomes are due to local support from family. Results with and without these restrictions are not substantially different, indicating that the role of family support in explaining differences in outcomes is negligible.
} 
(A) Labor force participation (LFP)
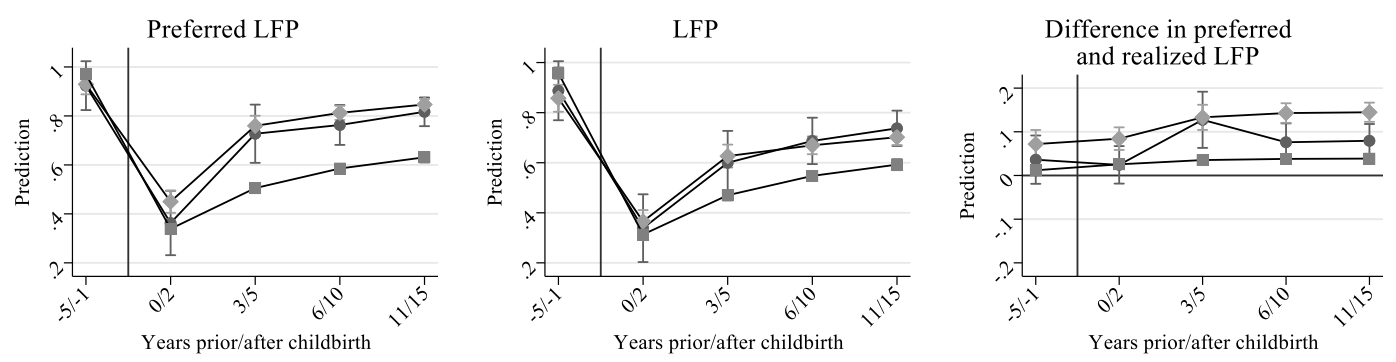

(B) Working hours
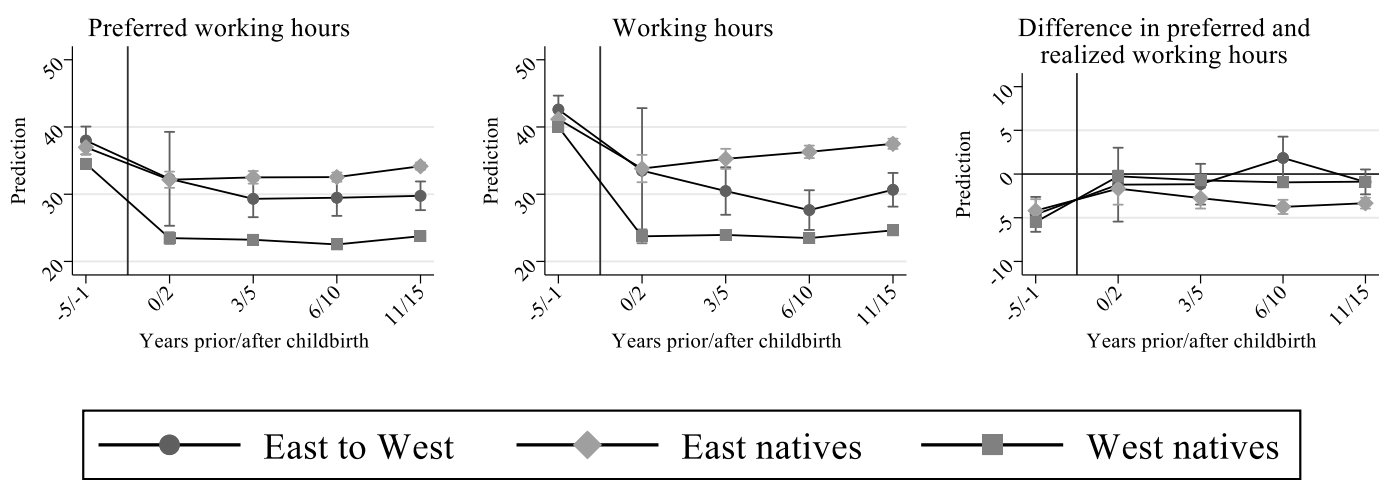

Figure 7: Differences in preferences and realized labor market outcomes (East to West movers vs. natives); predicted values with $95 \%$-CIS

First, focusing on the preferences for labor force participation in Panel A, we observe that mothers who moved from East to West do not significantly differ in their preference to work compared to mothers who stayed in East Germany. ${ }^{8}$ Work preferences of mothers who stayed in West Germany, however, are significantly lower after childbirth, mirroring the assumed differences in societal norms. The differences in the shares who would like to work amount up to about 20 percentage points the years after childbirth. The fact that preferences of movers do not align with preferences of West German mothers and remain similar to the ones of East German mothers speak for the importance of long-term effects of the societal context during the socialization period and against the importance of the societal context at the time of childbirth and childrearing. Even in the face of a change in the normative context and exposure to lower childcare provision in West Germany, East German mothers' substantially higher preferences to return remain unchanged. Focusing on Panel B, preferred working hours of movers are slightly lower compared to those of mothers who stayed in East Germany and substantially higher compared to those of West German mothers. The results again confirm that maternal work preferences,

\footnotetext{
${ }^{8}$ We merged yearly observations to the categories $0-3,3-6,6-11$, and $11+$ because the number of movers from East to West Germany precludes a more detailed analysis over time. We chose the categories to mirror age groups of the children that are associated with different care arrangements (nurseries, kindergarten, primary school, secondary school).
} 
shaped by the societal context are fairly stable even after moving to a different normative and institutional context.

Comparing mothers' work preferences with their employment outcomes allows us to test for direct effects of societal norms and to assess if lower levels of childcare provision in West Germany are at least partially responsible for the larger motherhood penalties. As the institutional framework has been aligned, we argue that any differences that remain after childcare expansion in West Germany should be attributable to direct effects of societal norms. For all groups, the development of labor force participation closely reflects the trajectories of the work preferences. The differences between realized and preferred employment are highest in East Germany, which reflects generally higher unemployment rates. The differences only slightly grow after childbirth, indicating no substantial difficulties in returning to the labor market to the desired degree. Differences between preferred and realized labor force participation of movers generally resemble the differences of West German mothers. However, they record an unusual peak three to five years after childbirth. While lower levels of childcare provision are likely not responsible for the peak (they would evoke greater differences before the age of three), it signifies that during a time when most East German mothers want to resume to work, they have the same difficulties to do so in East and West Germany. The result may imply difficulties when re-entering the labor market after a longer break. Because the peak only applies to East German mothers in West Germany and vanishes after a short period of time, it may also reflect random variation. In general, however, childcare provision does thus do not seem to prevent mothers from fulfilling their work preferences.

Focusing on working hours in Panel B, the graphs show a mostly similar pattern, but reveals one interesting exception. Realized working hours of movers diverge from those of East German mothers after two years. Interestingly, comparing preferred and actual working hours, West German mothers and mothers who moved from East to West Germany seem to be able to fulfill their preferences (the differences are not significantly different from 0). Mothers in East Germany on the other hand work more hours than they actually prefer. There are multiple potential explanations: First, as the economic situation in East Germany is worse and unemployment rates are higher, mothers may simply be forced to work longer hours than they want to. Second, as Collins (2019) described, while having a strong preference to work, many East German mothers often decide "not to pursue ambitious careers altogether, which seems to reflect both the socialist legacy that women work but also care for children, and the conservative model's mandate that women are responsible for the home". The consequence is a preference for lower working hours, which can better be met in West Germany's normative context.

In general, across all groups, work preferences and realized outcomes are mostly aligned in both more egalitarian East Germany and more traditional West Germany, but higher levels of unemployment in East Germany make it harder to fulfill preferences for labor force participation pre and post birth. The 
stability of the differences between preferences and outcomes indicates the importance of mothers' work preferences for shaping labor market outcomes and speaks against a direct influence of societal norms, e.g. through social sanctioning. We argued that employers, who-following their beliefs and preferences - might offer fewer or only part-time opportunities to mothers. In this case, discrepancies between preferred and realized labor market outcomes should be amplified if mothers who moved to West Germany preferred to work more or increase their hours. Regarding labor force participation and working hours, employers' beliefs, however, do not translate to obvious discriminatory hiring decisions or do not seem to reflect general societal norms. As previous studies have shown, discrimination might, however, be reflected in lower hourly wages, as motherhood is considered a devalued status in the labor market and mothers are perceived as less competent and committed to work (Correll et al., 2007; England, 2005; Ridgeway \& Correll, 2004, 2016). We cannot preclude general discrimination as hourly wages for mothers indeed develop less favorably for mothers in both East and West Germany (see Figure 4). However, we do not find any indication of a stronger disadvantage in West Germany.

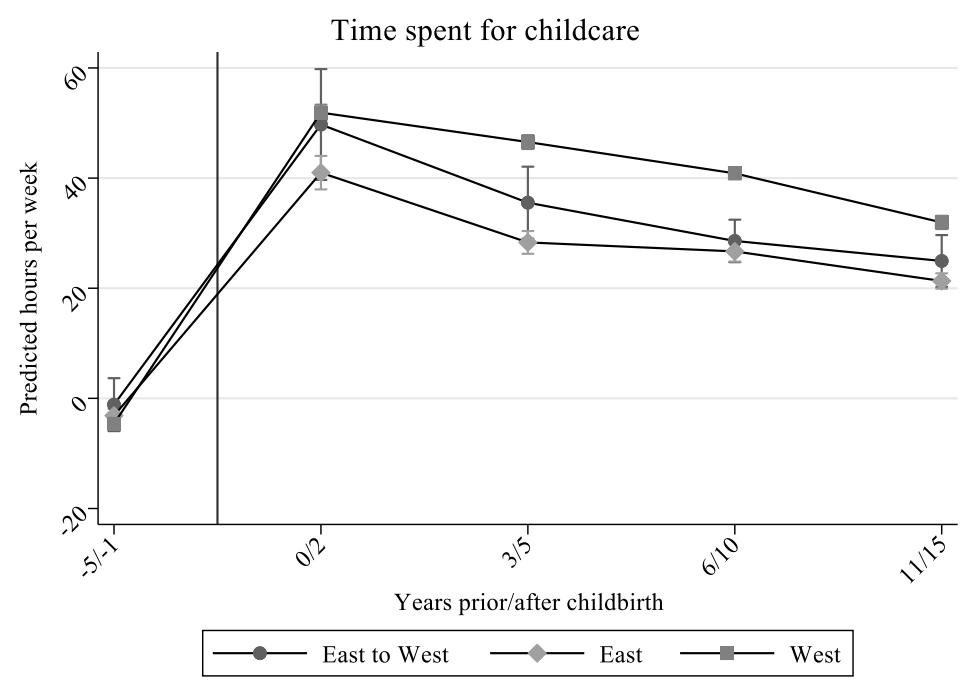

Figure 8: Time spent for childcare among mothers in East and West Germany; predicted values with 95\%-Cis

Lower public childcare availability also does not seem to mitigate East German mothers' ability to follow their preferences for higher labor force participation and working hours in West Germany. Additional analyses, splitting the sample into a period before and a period after childcare expansion in West Germany, confirm this notion and show that childcare expansion did not significantly increase labor force participation or working hours for mothers in West Germany (see online appendix B). The reason might be that public childcare availability simply crowds out informal childcare arrangements (Havnes \& Mogstad, 2011). East German mothers' higher attachment to the labor market, however, might theoretically come at the expense of other activities in case mothers who moved to West Germany 
have to privately compensate for the lower availability of public childcare institutions. As Figure 8 shows, mothers who move from East to West Germany do not invest more time in childcare at home compared to East Germany mothers in East Germany, while their West German counterparts do.

\section{Conclusion}

How do societal contexts affect motherhood penalties? While most studies focus on institutions to account for differences in mothers' wage penalties within and between countries, others refer to the influence of culture or a complex interaction between the two. We extend the previous literature in multiple ways: First, we argue that the societal context at the time of youth and adolescence should have a significant impact on the formation of work preferences, which in turn affect maternal labor market outcomes later in life. Second, we assess whether these work preferences are stable or adapt to new societal contexts. Third, we empirically investigate the direct effect of societal norms through sanctioning or employer discrimination. Changes in societal norms are slow and while norms can have an impact on institutions, institutions may also affect attitudes and beliefs, making it difficult to disentangle societal norms from institutions in cross-sectional, cross-country comparisons.

To empirically test these relationships, we make use of a unique historical setting: Germany's division into East and West Germany at the onset of the Cold War and its reunification and institutional alignment 40 years later. The German Democratic Republic (GDR) in East Germany followed a state socialist system, promoting women's full-time employment, while the Federal Republic of Germany (FRG) in West Germany followed a conservative welfare state and promoted a modernized version of the male-breadwinner model. After reunification, East Germany's institutional policies were mostly aligned, with the exception of continuously lower public childcare provision in West Germany. Gender norms, however, remained remarkably different. Economic necessities, but also pre-existing social ties, led to an unprecedented rate of migration from East to West during and after the period of East Germany's transition and many women, who had been socialized under egalitarian gender norms found themselves in a more traditional normative context.

Using panel data from the German Socio-Economic Panel (SOEP) and an event study design, we first show that after reunification, preferences regarding labor force participation and working hours as well as maternal labor market outcomes remain consistently different in East and West Germany. The alignment of the institutional framework as well as relocations into the more conservative context of West Germany did not substantially alter East German mothers' work preferences. They remain substantially higher compared to the preferences of West German mothers who grew up in a more conservative welfare regime. Likewise, the expansion of public childcare provision in West Germany did not affect maternal preferences. We thus conclude that socialization during youth and adolescence play a substantial role in forming stable maternal work preferences. Adult socialization on the other hand does not seem to matter for mothers' work preference. These results stand in contrast to previous 
studies emphasizing adaption of attitudes after migration. A likely explanation is that gender roles change very slowly (Su et al., 2010) and time in between migration and childbirth usually is short. Even in the long run, the societal context might not translate to maternal work preferences, because own experience might trump observed behavior and peer influence — especially for mothers' who realize that stronger work preferences can be fulfilled.

Because the development of work preferences and labor market outcomes before and after childbirth mostly align in both contexts, our results support the assumption that work preferences in turn affect labor market outcomes. They are restricted, however, by the economic realities in the respective regions. A larger number of women who would like to work cannot fulfill their preference in East Germany. Although having a preference for higher labor force participation and more working hours, mothers were mostly able to fulfill their work preferences even in the West German context with more conservative gender norms. The findings imply that - at least in our case and over the course of 15 years - societal norms at the time of childbirth do not have a direct effect on labor market outcomes. Neither social sanctioning nor employer discrimination regarding labor force participation or working hours seems to play a significant role. We find comparably slowed hourly wage growth for mothers both in East and West Germany. These results do not preclude employer discrimination regarding wages, but also leave open alternative mechanisms such as lower pay in mother-friendly occupations or in parttime work. The results, however, at least speak against an influence of societal norms on hiring discrimination.

Our results show that present societal norms do not seem to matter for motherhood penalties and the institutional alignment of East and West Germany as well as childcare expansion did not alter work preferences. By construction, however, our setting rules out the influence of present institutions in East and West Germany. In cases where these are aligned, we are unable to assess their influence on motherhood penalties. As other studies have shown that parental leave policies do affect maternal labor market outcomes, we assume that maternal work preferences in general and parts of the difference between preferences and outcomes can be attributed to such policies. Moreover, while we do not find an effect of childcare provision, others have shown that childcare institutions seem to be important when societal norms are aligned and emphasize how "cultural norms about mothers' employment interact with policies" (Budig et al., 2012). In other settings, in which institutional change follows normative change, institutions might thus very well play a role. Moreover, even though societal norms did not show a direct effect, they will likely impact motherhood penalties through shaping institutions. Likewise, societal norms are not cast in stone and institutional changes may in the long run contribute to the development of different societal norms. Even if policy changes thus seemingly have little effect, they might very well shape preferences and women's labor market outcomes in the future. Societal change is largely generated from processes of cohort replacement, and while this is associated with a slow rate of social 
change (Cunningham, 2008), societal norms at the time of childbirth should matter for the following generation.

Our insights on the direct effects of societal norms and the stability of maternal work preferences are based on mothers who move from a context with more egalitarian gender norms to one with more conservative gender norms. The directionality of the migration flows evoke the question whether or not we would expect the same findings when analyzing moves from conservative to more egalitarian contexts (a direction, which is also more likely to occur, given that societal changes most often occur "toward increased tolerance rather than increased conservatism" (Danigelis, Hardy, \& Cutler, 2007)). We assume that in more egalitarian contexts, institutions will likely not further restrict more traditional preferences from being fulfilled. As more egalitarian preferences were able to be fulfilled in West Germany, we thus argue that moving into a more gender-egalitarian context likely also has no shortterm effects on preferences and motherhood penalties, as long as other structural factors such as a disadvantaged employment situation emerge. Nonetheless, we cannot preclude that egalitarian norms shape preferences more easily than conservative norms.

Our results hold multiple implication. Research aiming to explain contextual differences in gendered outcomes and motherhood penalties in particular should take a look back in the lives of the respondents. While present policies surely affect women's labor market outcomes, it is the structural legacy of past norms and institutions that shape work preferences and paves the way for present work choices. Our findings also imply that developments in gendered outcomes are highly dependent on cultural changes across generations and cohorts. The process of work preference formation during youth and adolescence generate substantial time-lags in the impact of societal changes on labor market outcomes. The results also suggest that changing institutions alone might not be sufficient to alter labor market outcomes, in particular if appropriate work preferences are not present and when aiming at implementing more egalitarian institutions. In our case, mothers in West Germany, who potentially could increase labor market participation and work longer hours, do not do so. This also means that normative and institutional changes that do not show immediate effects might nonetheless find expression in the preferences of the following generations. Changes in women's work relations will likely have larger long-term effects on those who grow up to these changes and societal changes in gender relations will might create path dependencies and resonate long into the future.

\section{References}

Abendroth, A.-K., Huffman, M. L., \& Treas, J. (2014). The Parity Penalty in Life Course Perspective. American Sociological Review, 79(5), 993-1014. doi:10.1177/0003122414545986

Adler, M. A., \& Brayfield, A. (1996). East-West Differences in Attitudes about Employment anf Family in Germany. The Sociological Quaterly, 37(2), 245-268.

Aisenbrey, S., Evertsson, M., \& Grunow, D. (2009). Is There a Career Penalty for Mothers' Time Out? A Comparison of Germany, Sweden and the United States. Social Forces, 88(2), 573-606. 
Ajzen, I. (1991). The Theory of Planned Behavior. Organizational Behavior and human decision processes, 50, 179-211.

Amuedo-Dorantes, C., \& Kimmel, J. (2005). The Motherhood Wage Gap for Women in the United States: The Importance of College and Fertility Delay. Review of Economics of the Household, $3,17-48$.

Anderson, D. J., Binder, M., \& Krause, K. (2002). The Motherhood Wage Penalty: Which Mothers Pay It and Why? American Economic Journal: Papers and Proceedings, 92(2), 354-358.

Anderson, D. J., Binder, M., \& Krause, K. (2003). The Motherhood Wage Penalty Revisited: Experience, Heterogeneity, Work Effort, and Work-Schedule Flexibility. ILR Review, 56(2), 273-294

Angrist, J. D., \& Evans, W. N. (1998). Children and Their Parents' Labor Supply: Evidence from Exogenous Variation in Family Size. The American Economic Review, 88(3), 450-477.

Auspurg, K., Hinz, T., \& Sauer, C. (2017). Why Should Women Get Less? Evidence on the Gender Pay Gap from Multifactorial Survey Experiments. American Sociological Review, 82(1), 179-210. doi:10.1177/0003122416683393

Avellar, S., \& Smock, P. J. (2003). Has the Price of Motherhood Declined Over Time? A Cross-Cohort Comparison of the Motherhood Wage Penalty. Journal of Marriage and Family, 65, 597-607.

Baker, M., Gruber, J., \& Milligan, K. (2008). Universal Child Care, Maternal Labor Supply, and Family Well-Being. Journal of Political Economy, 116, 709-745.

Bauernschuster, S., \& Rainer, H. (2011). Political regimes and the family: how sex-role attitudes continue to differ in reunified Germany. Journal of Population Economics, 25(1), 5-27. doi:10.1007/s00148-011-0370-z

Becker, G. S. (1985). Human Capital, Effort, and the Sexual Division of Labor. Journal of Labor Economics, 3(1, Part 2: Trends in Women's Work, Education, and Family Building), S33-S58.

Becker, G. S. (1993). A Treatise on the Family: Harvard university press.

Benard, S., \& Correll, S. J. (2010). Normative Discrimination and the Motherhood Penalty. Gender \& society, 24(5), 616-646. doi:10.1177/0891243210383142

Berlinski, S., \& Galiani, S. (2007). The effect of a large expansion of pre-primary school facilities on preschool attendance and maternal employment. Labour Economics, 14(3), 665-680. doi:10.1016/j.labeco.2007.01.003

Bettendorf, L. J. H., Jongen, E. L. W., \& Muller, P. (2015). Childcare subsidies and labour supplyEvidence from a large Dutch reform. Labour Economics, 36, 112-123.

Bianchi, S. M., Milkie, M. A., Sayer, L. C., \& Robinson, J. P. (2000). Is Anyone Doing the Housework? Trends in the Gender Division of Household Labor. Social Forces, 79(1), 191-228.

Bittmann, M., England, P., Sayer, L., Folbre, N., \& Matheson, G. (2003). When Does Gender Trump Money? Bargaining and Time in Household Work. American Journal of Sociology, 109(1), 186214.

Blau, F. D., \& Kahn, L. M. (2006). The US gender pay gap in the 1990s: Slowing convergence. ILR Review, 60(1), 45-66.

Boeckmann, I., Misra, J., \& Budig, M. J. (2014). Cultural and Institutional Factors Shaping Mothers' Employment and Working Hours in Postindustrial Countries. Social Forces, 93(4), 1301-1333. doi:10.1093/sf/sou119

Bronars, S. G., \& Grogger, J. (1994). The Economic Consequences of Unwed Motherhood: Using Twin Births as a Natural Experiment. The American Economic Review, 84(5), 1141-1156.

Budig, M. J., \& England, P. (2001). The Wage Penalty for Motherhood. American Sociological Review, 66(2), 204-225.

Budig, M. J., \& Hodges, M. J. (2010). Differences in Disadvantage. American Sociological Review, 75(5), 705-728. doi:10.1177/0003122410381593

Budig, M. J., Misra, J., \& Boeckmann, I. (2012). The Motherhood Penalty in Cross-National Perspective: The Importance of Work-Family Policies and Cultural Attitudes. Social Politics: International Studies in Gender, State \& Society, 19(2), 163-193. doi:10.1093/sp/jxs006

Busse, A., \& Gathmann, C. (2018). Free Daycare and its Effects on Children and their Families. SOEPpapers, 958, 1-61. 
Carter, J. S., \& Carter, S. K. (2014). Place matters: the impact of place of residency on racial attitudes among regional and urban migrants. Soc Sci Res, 47, 165-177. doi:10.1016/j.ssresearch.2014.04.001

Cascio, E. U. (2009). Maternal Labor Supply and the Introduction of Kindergartens into American Public Schools. Journal of Human Resources, 44(1), 140-170. doi:10.1353/jhr.2009.0034

Cohen, P. N., \& Bianchi, S. M. (1999). Marriage, children, and women's employment: what do we know? Monthly Labor Review, 122, 22-31.

Collins, C. (2019). Making motherhood work: How women manage careers and caregiving: Princeton University Press.

Cooke, L. P. (2006). Policy, Preferences, and Patriarchy: The Division of Domestic Labor in East Germany, West Germany, and the United States. Social Politics: International Studies in Gender, State \& Society, 13(1), 117-143. doi:10.1093/sp/jxj005

Correll, S. J., Bernard, S., \& Paik, I. (2007). Getting a Job: Is There a Motherhood Penalty? American Journal of Sociology, 112(5), 1297-1338.

Cukrowska-Torzewska, E., \& Matysiak, A. (2020). The motherhood wage penalty: A meta-analysis. Social Science Research. doi:10.1016/j.ssresearch.2020.102416

Cunningham, M. (2008). Changing Attitudes toward the Male Breadwinner, Female Homemaker Family Model: Influences of Women's Employment and Education over the Lifecourse. Social Forces, 87(1), 299-323.

Danigelis, N. L., Hardy, M., \& Cutler, S. J. (2007). Population Aging, Intracohort Aging, and Sociopolitical Attitudes. American Sociological Review, 72, 812-830.

Dion, K. K., \& Dion, K. L. (2001). Gender and Cultural Adaptation in Immigrant Families. Journal of Social Issues, 57(3).

England, P. (2005). Gender inequality in labor markets: The role of motherhood and segregation. Social Politics: International Studies in Gender, State \& Society, 12(2), 264-288.

England, P. (2010). The gender revolution: Uneven and stalled. Gender \& society, 24(2), 149-166.

England, P., Bearak, J., Budig, M. J., \& Hodges, M. J. (2016). Do Highly Paid, Highly Skilled Women Experience the Largest Motherhood Penalty? American Sociological Review, 81(6), 1161-1189. doi: $10.1177 / 0003122416673598$

England, P., Levine, A., \& Mishel, E. (2020). Is the Gender Revolution Stalled? An Update. Proceedings of the National Academy of Sciences, forthcoming, 1-37.

Evertsson, M., \& Duvander, A. Z. (2011). Parental Leave--Possibility or Trap? Does Family Leave Length Effect Swedish Women's Labour Market Opportunities? European Sociological Review, 27(4), 435-450. doi:10.1093/esr/jcq018

Farré, L., \& Vella, F. (2013). The Intergenerational Transmission of Gender Role Attitudes and its Implications for Female Labour Force Participation. Economica, 80(318), 219-247. doi:10.1111/ecca.12008

Fernández, R., Fogli, A., \& Olivetti, C. (2004). Mothers and Sons: Preference Formation and Female Labor Force Dynamics. The Quarterly Journal of Economics, 119(4), 1249-1299.

Fortin, N. M. (2005). Gender Role Attitudes and the Labour-market Outcomes of Women across OECD Countries. Oxford Review of Economic Policy, 21(3), 416-438. doi:10.1093/oxrep/gri024

Frodermann, C., \& Müller, D. (2019). Establishment Closures in Germany: The Motherhood Penalty at Job Search Durations. European Sociological Review, 35(6), 845-859. doi:10.1093/esr/jcz043

Fuchs-Schündeln, N., \& Schündeln, M. (2009). Who stays, who goes, who returns? East--West migration within Germany since reunification. Economics of Transition, 17(4), 703-738.

Gangl, M., \& Ziefle, A. (2009). Motherhood, labor force behavior, and women's careers: An empirical assessment of the wage penalty for motherhood in Britain, Germany, and the United States. Demography, 46(2), 341-369.

Gangl, M., \& Ziefle, A. (2015). The Making of a Good Woman: Extended Parental Leave Entitlements and Mothers' Work Commitment in Germany. American Journal of Sociology, 121(2), 511563.

Gash, V. (2008). Preference or constraint? Part-time workers' transitions in Denmark, France and the United Kingdom. Work, Employment and Society, 22(4), 655-674. doi:10.1177/0950017008096741 
Gathmann, C., \& Sass, B. (2018). Taxing Childcare: Effects on Childcare Choices,Family Labor Supply and Children. Journal of Labor Economics, 36(3), 665-709.

Gerson, K. (2009). The unfinished revolution: Coming of age in a new era of gender, work, and family: Oxford University Press.

Glaser, J. M., \& Gilens, M. (1997). Interregional Migration and Political Resocialization: A Study of Racial Attitudes Under Pressure. The Public Opinion Quaterly, 61(1), 72-86.

Glauber, R. (2007). Marriage and the Motherhood Wage Penalty Among African Americans, Hispanics, and Whites. Journal of Marriage and Family, 69, 951-961.

Glauber, R. (2018). Trends in the Motherhood Wage Penalty and Fatherhood Wage Premium for Low, Middle, and High Earners. Demography, 55(5), 1663-1680. doi:10.1007/s13524-018-0712-5

Goldin, C. (2014). A Grand Gender Convergence: Its Last Chapter. American Economic Review, 104(4), 1091-1119. doi:10.1257/aer.104.4.1091

Gupta, S. (1999). The Effects of Transitions in Marital Status on Men's Performance of Housework. Journal of Marriage and Family, 61(3), 700-711.

Hakim, C. (2000). Work-lifestyle choices in the 21st century: Preference theory. New York: Oxford University Press.

Han, W., \& Waldfogel, J. (2001). Child Care Costs and Women's Employment: A Comparison of Single and Married Mothers With Pre-School-Aged Children. Social Science Quaterly, 82(3), 552-568.

Harkness, S., \& Waldfogel, J. (2003). The Family Gap in Pay: Evidence from Seven Industrialized Countries. Research in Labor Economics, 22, 369-413. doi:10.1016/s0147-9121(03)22012-4

Havnes, T., \& Mogstad, M. (2011). Money for nothing? Universal child care and maternal employment. Journal of Public Economics, 95(11-12), 1455-1465. doi:10.1016/j.jpubeco.2011.05.016

Himmelweit, S., \& Sigala, M. (2004). Choice and the Relationship between Identities and Behaviour for Mothers with Pre-School Children: Some Implications for Policy from a UK Study. Journal of Social Policy, 33(3), 455-478. doi:10.1017/s0047279404007779

Hipp, L. (2019). Do Hiring Practices Penalize Women and Benefit Men for Having Children? Experimental Evidence from Germany. European Sociological Review. doi:10.1093/esr/jcz056

Hirsch, B. T. (2005). Why Do Part-Time Workers Earn Less? The Role of Worker and Job Skills. ILR Review, 58(4), 525-551.

Hodgson, G. M. (2016). What Are Institutions? Journal of Economic Issues, 40(1), 1-25. doi:10.1080/00213624.2006.11506879

Holst, E., \& Schupp, J. (2001). Erwerbsverhalten von Frauen: trotz Annäherung immer noch deutliche Unterschiede zwischen Ost und West. DIW Wochenbericht, 68(42), 648-658.

Hotz, V. J., Williams McElroy, S., \& Sanders, S. G. (2005). Teenage Childbearing and Its Life Cycle Consequences: Exploiting a Natural Experiment. The Journal of Human Resources, 40(3), 683715.

Huebener, M., Pape, A., \& Spiess, C. K. (2019). Parental Labour Supply Responses to the Abolition of Day Care Fees. IZA Discussion Paper No. 12780.

Huffman, M. L., King, J., \& Reichelt, M. (2017). Equality for whom? Organizational policies and the gender gap across the German earnings distribution. ILR Review, 70(1), 16-41.

Kjeldstad, R., \& Nymoen, E. H. (2012). Part-time work and gender: Worker versus job explanations. International Labour Review, 151(1-2), 85-107.

Klerman, J. A., \& Arleen, L. (1999). Job continuity among new mothers. Demography, 36(2), 145-155.

Kleven, H., Landais, C., Posch, J., Steinhauer, A., \& Zweimüller, J. (2019). Child Penalties across Countries: Evidence and Explanations. AEA Papers and Proceedings, 109, 122-126. doi: $10.1257 /$ pandp. 20191078

Kleven, H., Landais, C., \& Søgaard, J. E. (2019). Children and Gender Inequality: Evidence from Denmark. American Economic Journal: Applied Economics, 11(4), 181-209. doi: $10.1257 /$ app.20180010

Kluve, J., \& Tamm, M. (2012). Parental leave regulations, mothers' labor force attachment and fathers' childcare involvement: evidence from a natural experiment. Journal of Population Economics, 26(3), 983-1005. doi:10.1007/s00148-012-0404-1

Kremer, M. (2006). The Politics of Ideals of Care: Danish and Flemish Child Care Policy Compared. Social Politics: International Studies in Gender, State \& Society, 13(2), 261-285. doi:10.1093/sp/jxj009 
Kremer, M. (2007). How welfare states care: Culture, gender and parenting in Europe: Amsterdam University Press.

Kühhirt, M. (2012). Childbirth and the Long-Term Division of Labour within Couples: How do Substitution, Bargaining Power, and Norms affect Parents' Time Allocation in West Germany? European Sociological Review, 28(5), 565-582. doi:10.1093/esr/jcr026

Kühhirt, M., \& Ludwig, V. (2012). Domestic Work and the Wage Penalty for Motherhood in West Germany. Journal of Marriage and Family, 74(1), 186-200. doi:10.1111/j.17413737.2011.00886.x

Künn-Nelen, A., De Grip, A., \& Fourage, D. (2013). Is Part-Time Employment Benefiial for Firm Productivity? ILR Review, 66(5), 1172-1191.

Künzler, J., Walter, W., Reichart, E., \& Pfisster, G. (2001). Gender division of labour in unified Germany. Retrieved from Tilburg: Tilburg Univ. Press:

Lalive, R., \& Zweimüller, J. (2009). How does parental leave affect fertilify andd return to work? Evidence from two natural experiments. The Quarterly Journal of Economics, 124(3), 13631402.

Leaper, C., \& Valin, D. (1996). Predictors of Mexican American Mothers' and Fathers' Attitudes Toward Gender Equality. Hispanic Journal of Behavioral Sciences, 18(3), 343-355.

Lefebvre, P., \& Merrigan, P. (2008). Child-Care Policy and the Labor Supply of Mothers with Young Children: A Natural Experiment from Canada. Journal of Labor Economics, 26(3), 519-548.

Lewis, J. (1992). Gender and the development of welfare regimes. Journal of European Social Policy, 2(3), 159-173.

Lundin, D., Mörk, E., \& Öckert, B. (2008). How far can reduced childcare prices push female labour supply? Labour Economics, 15(4), 647-659. doi:10.1016/j.labeco.2008.04.005

Miller, A. R. (2009). The effects of motherhood timing on career path. Journal of Population Economics, 24(3), 1071-1100. doi:10.1007/s00148-009-0296-x

Miller, S. D., \& Sears, D. O. (1986). Stability and Change in Social Tolerance: A Test of the Persistence Hypothesis. American Journal of Political Science, 30(1), 214-236.

Mincer, J., \& Polachek, S. W. (1974). Family investments in human capital: Earnings of women. Journal of Political Economy, 82(2, Part 2), S76-S108.

Naz, G. (2004). The impact of cash-benefit reform on parents? labour force participation. Journal of Population Economics, 17(2), 369-383. doi:10.1007/s00148-003-0157-y

Neumark, D., \& Korenman, S. (1994). Sources of bias in women's wage equations: Results using sibling data. The Journal of Human Resources, 29(2), 379-405.

Norris, P., \& Inglehart, R. F. (2012). Muslim Integration into Western Cultures: Between Origins and Destinations. Political Studies, 60(2), 228-251. doi:10.1111/j.1467-9248.2012.00951.x

Orloff, A. (1996). Gener in the Welfare State. Annual Review of Sociology, 22, 51-78.

Parrado, E. A., \& Flippen, C. A. (2005). Migration and Gender among Mexican Women. American Sociological Review, 70(4), 606-632.

Perry, S. (1990). Part-time work and returning to work after the birth of the first child. Applied Economics, 22(9), 1137-1148. doi:10.1080/00036849000000035

Pettit, B., \& Hook, J. (2005). The Structure of Women's Employment in Comparative Perspective. Social Forces, 84(2), 779-801.

Pettit, B., \& Hook, J. L. (2009). Gendered tradeoffs: Women, family, and workplace inequality in twentyone countries: Russell Sage Foundation.

Pfau-Effinger, B. (1993). Modernisation, Culture, and Part-time employemnt Work, Employment and Society, 7(3), 383-410.

Pfau-Effinger, B. (2004). Culture and Welfare State Policies: Reflections on a Complex Interrelation. Journal of Social Policy, 34(1), 3-20. doi:10.1017/s0047279404008232

Pfau-Effinger, B., \& Geissler, B. (2002). Cultural change and family policies in East and West Germany. In A. Carling, S. Duncan, \& R. Edwards (Eds.), Analysing Families: Morality and rationality in policy and practice (pp. 77-83). New York: Routledge.

Pfau-Effinger, B. (1998). Gender cultures and the gender arrangement-a theoretical framework for cross-national gender research. Innovation: The European Journal of Social Science Research, 11(2), 147-166. doi:10.1080/13511610.1998.9968559 
Platt, L., \& Polavieja, J. (2016). Saying and Doing Gender: Intergenerational Transmission of Attitudes towards the Sexual Division of Labour. European Sociological Review, 32(6), 820-834. doi:10.1093/esr/jcw037

Ridgeway, C. L., \& Correll, S. J. (2004). Motherhood as a Status Characteristic. Journal of Social Issues, 60(4), 683-700.

Ridgeway, C. L., \& Correll, S. J. (2016). Unpacking the Gender System. Gender \& society, 18(4), 510531. doi:10.1177/0891243204265269

Röder, A., \& Mühlau, P. (2014). Are They Acculturating? Europe's Immigrants and Gender Egalitarianism. Social Forces, 92(3), 899-928. doi:10.1093/sf/sot126

Rosenfeld, R. A., Trappe, H., \& Gornick, J. C. (2004). Gender and Work in Germany: Before and After Reunification. Annual Review of Sociology, 30(1), 103-124. doi:10.1146/annurev.soc.30.012703.110531

Sainsbury, D. (1999). Gender and welfare state regimes: Oxford University Press.

Sanchez, L., \& Thomson, E. (1997). Becoming Mothers and Fathers: Parenthood, Gender, and the Division of Labor. Gender \& society, 11(6), 747-772.

Schøne, P. (2004). Labour supply effects of a cash-for-care subsidy. Population Economics, 17(4), 703727. doi:10.1007/s00148-003-0176-8

Sigle-Rushton, W., \& Waldfogel, J. (2007). Motherhood and women's earnings in Anglo-American, Continental European, and Nordic Countries. Feminist Economics, 13(2), 55-91. doi:10.1080/13545700601184849

South, S. J., \& Spitze, G. (1994). Housework in Marital and Nonmarital Households. American Sociological Review, 59(3), 327-347.

Staff, J., \& Mortimer, J. T. (2012). Explaining the motherhood wage penalty during the early occupational career. Demography, 49(1), 1-21. doi:10.1007/s13524-011-0068-6

Steiber, N., \& Haas, B. (2009). Ideals or compromises? The attitude-behaviour relationship in mothers' employment. Socio-Economic Review, 7(4), 639-668. doi:10.1093/ser/mwp015

Steiber, N., \& Haas, B. (2012). Advances in explaining women's employment patterns. Socio-Economic Review, 10(2), 343-367. doi:10.1093/ser/mwr039

Stier, H., Lewin-Epstein, N., \& Braun, M. (2001). Welfare Regimes, Family-Supportive Policies, and Women's Employment along the Life-Course. American Journal of Sociology, 106(6), 17311760 .

Su, D., Richardson, C., \& Wang, G.-z. (2010). Assessing Cultural Assimilation of Mexican Americans: How Rapidly Do Their Gender-Role Attitudes Converge to the U.S. Mainstream? Social Science Quaterly, 91(3), 762-776.

Thornton, A., Alwin, D. F., \& Camburn, D. (1983). Causes and Consequences of Sex-Role Attitudes and Attitude Change. American Sociological Review, 48(2), 211-227.

Trappe, H. (1996). Work and Family in Woemn's Lives in the German Democratic Republic. Work and Occupations, 23(4), 354-377.

Tyler, T. R., \& Schuller, R. A. (1991). Aging and Attitude Change. Journal of Personality and Social Psychology, 61(5), 689-697.

Uunk, W. (2015). Does the Cultural Context Matter? The effect of a country's gender-role attitudes on female labor supply. European Societies, 17(2), 176-198. doi:10.1080/14616696.2014.995772

Uunk, W., Kalmijn, M., \& Muffels, R. (2016). The Impact of Young Children on Women's Labour Supply. Acta Sociologica, 48(1), 41-62. doi:10.1177/0001699305050986

Uunk, W., \& Lersch, P. M. (2019). The Effect of Regional Gender-Role Attitudes on Female Labour Supply: A Longitudinal Test Using the BHPS, 1991-2007. European Sociological Review, 35(5), 669-683. doi:10.1093/esr/jcz026

van der Lippe, T., de Ruijter, J., de Ruijter, E., \& Raub, W. (2011). Persistent Inequalities in Time Use between Men and Women: A Detailed Look at the Influence of Economic Circumstances, Policies, and Culture. European Sociological Review, 27(2), 164-179.

Vella, F. (1994). Gender Roles and Human Capital Investment: The Relationship between Traditional Attitudes and Female Labour Market Performance. Economica, New Series, 61(242), 191-211.

Wagner, G. G., Frick, J. R., \& Schupp, J. (2007). Enhancing the power of household panel studies: The case of the German Socio-Economic Panel Study (SOEP). Schmollers Jahrbuch 127(1), 139169. 
Waldfogel, J. (1997). The Effect of Children on Women's Wages. American Sociological Review, 62(2), 209-217.

Waldfogel, J. (1998a). The Family Gap for Young Women in the United States and Britain: Can Maternity Leave Make a Difference? Journal of Labor Economics, 16(3), 505-545.

Waldfogel, J. (1998b). Understanding the "Family Gap" in Pay for Women with Children. Journal of Economic Perspectives, 12(1), 137-156.

Webber, G., \& Williams, C. (2008). Mothers in "Good" and "Bad" Part-time Jobs. Gender \& society, 22(6), 752-777. doi: $10.1177 / 0891243208325698$

Wilde, E. T., Batchelder, L., \& Ellwood, D. T. (2010). The Mommy Track Divides: The Impact of Childbearing on Wages of Women of Differing Skill Levels. NBER Working Paper Series, $16582,1-45$.

Zoch, G., \& Hondralis, I. (2017). The Expansion of Low-Cost, State-Subsidized Childcare Availability and Mothers' Return-to-Work Behaviour in East and West Germany. European Sociological Review, 33(5), 693-707. doi:10.1093/esr/jcx068

Zoch, G., \& Schober, P. S. (2018). Public Childcare Expansion and Changing Gender Ideologies of Parents in Germany. Journal of Marriage and Family, 80(4), 1020-1039. 


\section{Appendix}

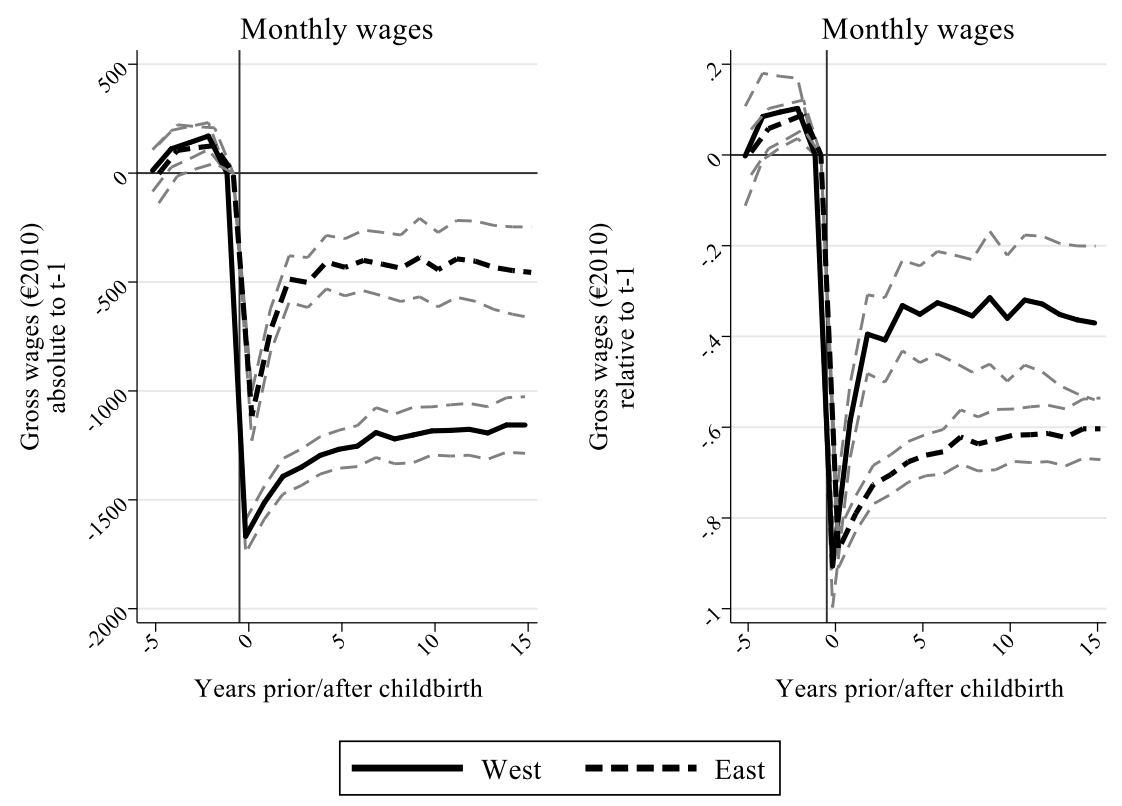

Figure A 1: Motherhood Penalty as absolute (in EUR) and relative (as percentage of Wages in $t=-1$ ) with 95\%-CIs. 
(A) Partner earns below median
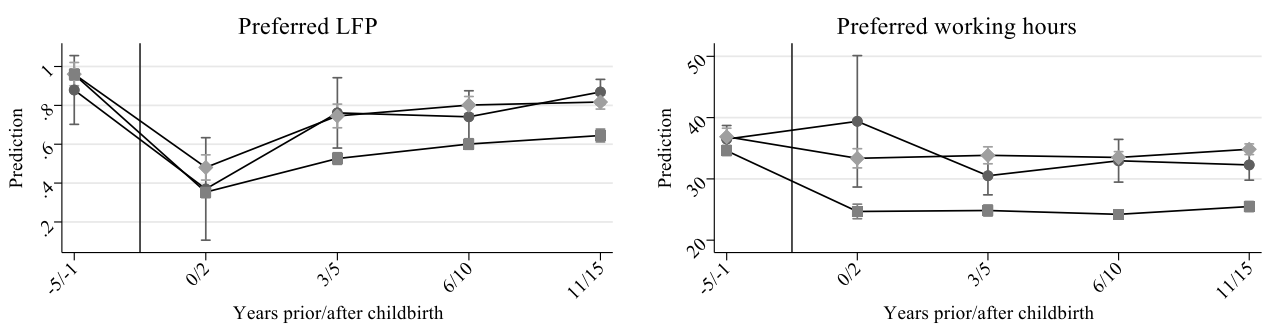

(B) Partner earns above median
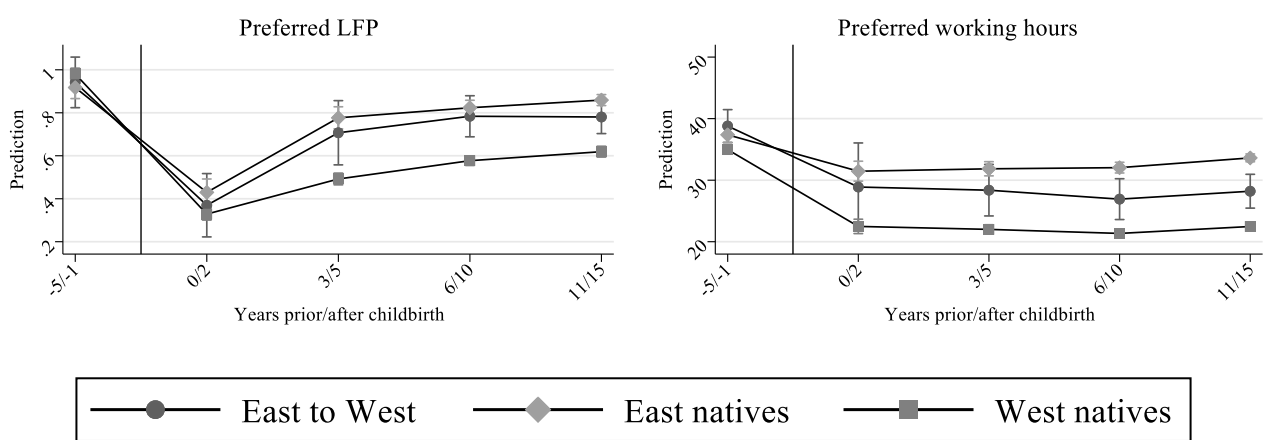

Figure A 2: Maternal work preferences by partner's earnings; predicted values with 95\%-CIs 
(A) Before 2006
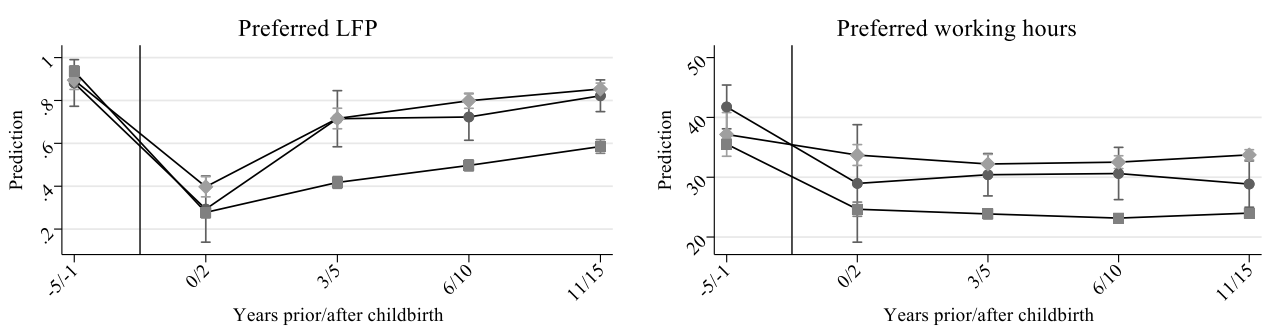

(B) After 2006
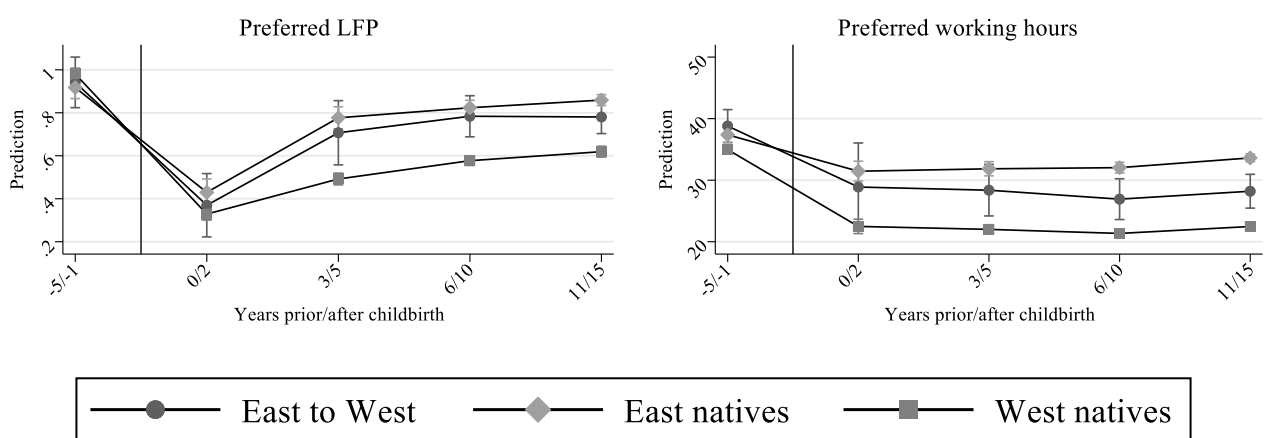

Figure A 3 Maternal work preferences in context with higher unemployment rates (before 2006) and lower unemployment rates (after 2006); predicted values with 95\%-CIs 
TABLE A 1: SAMPLE DESCRIPTIVES FOR MOTHERS

\begin{tabular}{|c|c|c|c|c|c|c|c|c|}
\hline & $\begin{array}{c}(1) \\
\text { West }\end{array}$ & $\begin{array}{l}(2) \\
\text { East }\end{array}$ & $\begin{array}{c}(3) \\
\text { East-West } \\
\text { mover } \\
\text { (all) }\end{array}$ & $\begin{array}{c}(4) \\
\text { East-East } \\
\text { mover } \\
\text { (all) }\end{array}$ & $\begin{array}{l}\text { (5) } \\
\text { West-West mover } \\
\text { (all) }\end{array}$ & $\begin{array}{c}(6) \\
\text { East-West mover } \\
\text { (working) }\end{array}$ & $\begin{array}{c}(7) \\
\text { East-East mover } \\
\text { (working) }\end{array}$ & $\begin{array}{c}(8) \\
\text { West-West mover } \\
\text { (working) }\end{array}$ \\
\hline Age & 35.073 & 32.251 & 33.615 & 32.569 & 34.085 & 34.534 & 33.525 & 34.446 \\
\hline Survey year & 2004.542 & 2004.006 & 2002.534 & 2004.232 & 2005.412 & 2003.706 & 2005.143 & 2005.789 \\
\hline $\begin{array}{l}\text { Years of } \\
\text { schooling }\end{array}$ & 12.566 & 12.851 & 12.720 & 13.134 & 12.826 & 12.821 & 13.320 & 13.153 \\
\hline $\begin{array}{l}\text { Number of } \\
\text { children at } \mathrm{t}=10\end{array}$ & 1.933 & 1.792 & 1.627 & 1.657 & 1.879 & 1.574 & 1.607 & 1.764 \\
\hline $\mathrm{N}$ & 31062 & 9925 & 710 & 1098 & 3977 & 446 & 746 & 2264 \\
\hline
\end{tabular}


TABLE A 2: REgRESSION RESULTS CORRESPONDING TO FIG. 5 AND 6

\begin{tabular}{|c|c|c|c|c|c|c|c|c|c|c|}
\hline & $\begin{array}{c}1) \\
\text { Ln(wage) } \\
\text { East } \\
\end{array}$ & $\begin{array}{c}\text { (2) } \\
\text { Ln(wage) } \\
\text { West }\end{array}$ & $\begin{array}{l}(3) \\
\text { LFP } \\
\text { East }\end{array}$ & $\begin{array}{l}(4) \\
\text { LFP } \\
\text { West } \\
\end{array}$ & $\begin{array}{c}(5) \\
\text { Working hours } \\
\text { East } \\
\end{array}$ & $\begin{array}{c}(6) \\
\text { Working hours } \\
\text { West } \\
\end{array}$ & $\begin{array}{c}(7) \\
\text { Preferred LFP } \\
\text { East }\end{array}$ & $\begin{array}{c}(8) \\
\text { Preferred LFP } \\
\text { West }\end{array}$ & $\begin{array}{c}(9) \\
\text { Preferred working } \\
\text { hours - East }\end{array}$ & $\begin{array}{c}(10) \\
\text { Preferred working } \\
\text { hours - West }\end{array}$ \\
\hline \multicolumn{11}{|l|}{$\begin{array}{l}\text { Time to } \\
\text { childbirth }\end{array}$} \\
\hline-5 & 0.009 & $\begin{array}{l}-0.006 \\
-0.019)\end{array}$ & $0.088^{*}$ & $0.061^{* *}$ & $\begin{array}{l}-0.164 \\
-0.849)\end{array}$ & 0.570 & $0.078^{*}$ & $0.058^{* *}$ & $\begin{array}{l}1.145 \\
0.0796\end{array}$ & $0.926^{*}$ \\
\hline-4 & 0.048 & -0.005 & $0.112^{* * * *}$ & $0.093^{* * * *}$ & -0.200 & $\begin{array}{c}(0.437) \\
0.219\end{array}$ & $0.084^{* *}$ & $0.090^{* * * *}$ & 0.725 & $1.009^{* *}$ \\
\hline & $(0.034)$ & $(0.017)$ & $(0.031)$ & $(0.016)$ & $(0.789)$ & $(0.371)$ & $(0.029)$ & $(0.015)$ & $(0.663)$ & $(0.348)$ \\
\hline-3 & 0.012 & -0.021 & $0.103^{* * * *}$ & $0.086^{* * *}$ & $\begin{array}{c}0.923 \\
0.502\end{array}$ & $0.752^{*}$ & $0.113^{* * * *}$ & $0.094^{* * * *}$ & 0.935 & $1.045^{* * * *}$ \\
\hline-2 & $\begin{array}{l}(0.030) \\
-0.006\end{array}$ & $\begin{array}{c}(0.014) \\
-0.010\end{array}$ & $\begin{array}{l}(0.027) \\
0.100^{* * * *}\end{array}$ & $\begin{array}{l}(0.014) \\
0.098^{* * * *}\end{array}$ & $\begin{array}{l}(0.593) \\
1.309^{*}\end{array}$ & $\begin{array}{c}(0.304) \\
0.445\end{array}$ & $\begin{array}{l}(0.025) \\
0.115^{* * *}\end{array}$ & $\begin{array}{l}(0.013) \\
0.114^{* * * *}\end{array}$ & $\begin{array}{c}(0.547) \\
0.780\end{array}$ & $(0.310)$ \\
\hline-2 & $\begin{array}{l}-0.000 \\
(0.026)\end{array}$ & $\begin{array}{l}-0.010 \\
(0.011)\end{array}$ & $\begin{array}{l}0.100 \\
(0.025)\end{array}$ & $\begin{array}{l}0.098 \\
(0.012)\end{array}$ & $\begin{array}{l}1.309^{*} \\
(0.575)\end{array}$ & $\begin{array}{l}0.445 \\
(0.261)\end{array}$ & $\begin{array}{l}0.115 \\
(0.022)\end{array}$ & $\begin{array}{l}0.114 \\
(0.011)\end{array}$ & $\begin{array}{c}0.780 \\
(0.442)\end{array}$ & $\begin{array}{l}0.917 \\
(0.258)\end{array}$ \\
\hline-1 & & & & Ref. & & & & & & \\
\hline 0 & $\begin{array}{l}-0.021 \\
(0.072)\end{array}$ & $\begin{array}{l}-0.091^{*} \\
(0.037)\end{array}$ & $\begin{array}{c}-0.624^{* * * *} \\
(0.027)\end{array}$ & $\begin{array}{c}-0.683^{* * *} \\
(0.014)\end{array}$ & $\begin{array}{l}-3.094 \\
(1.853)\end{array}$ & $\begin{array}{c}-7.385^{* * *} \\
(1.077)\end{array}$ & $\begin{array}{c}-0.649^{* * * *} \\
(0.026)\end{array}$ & $\begin{array}{c}-0.681^{* * * *} \\
(0.014)\end{array}$ & $\begin{array}{c}-0.649 * * * \\
(0.026)\end{array}$ & $\begin{array}{c}-0.681^{* * * *} \\
(0.014)\end{array}$ \\
\hline 1 & $\begin{array}{l}(0.0 / 2) \\
-0.050 \\
(0.039)\end{array}$ & $\begin{array}{l}(0.03) * * \\
-0.080^{* * *} \\
(0.022)\end{array}$ & $\begin{array}{l}(0.027) * \\
-0.415^{* * *} \\
(0.029)\end{array}$ & $\begin{array}{l}(0.014) \\
-0.584^{* * *} \\
(0.015)\end{array}$ & $\begin{array}{l}(1.83) \\
-5.533^{* * * *} \\
(0.926)\end{array}$ & $\begin{array}{c}-14.763^{* * * *} \\
(0.715)\end{array}$ & $\begin{array}{l}(0.020) * \\
-0.388^{* * *} \\
(0.030)\end{array}$ & $\begin{array}{l}-0.0142^{* * * *} \\
(0.015)\end{array}$ & $\begin{array}{c}(0.020) \\
-0.388^{* * * *} \\
(0.030)\end{array}$ & $\begin{array}{c}(0.014) \\
-0.562 * * * \\
(0.015)\end{array}$ \\
\hline 2 & $\begin{array}{l}-0.072^{*} \\
(0.035)\end{array}$ & $\begin{array}{c}-0.100^{* * * *} \\
(0.019)\end{array}$ & $\begin{array}{c}-0.223^{* * * *} \\
(0.030)\end{array}$ & $\begin{array}{c}-0.502^{* * * *} \\
(0.016)\end{array}$ & $\begin{array}{l}-4.222^{* * * *} \\
(0.851)\end{array}$ & $\begin{array}{c}-14.370^{* * * *} \\
(0.575)\end{array}$ & $\begin{array}{c}-0.152^{* * * *} \\
(0.030)\end{array}$ & $\begin{array}{c}-0.486^{* * * *} \\
(0.016)\end{array}$ & $\begin{array}{c}-0.152^{* * *} \\
(0.030)\end{array}$ & $\begin{array}{c}-0.486^{* * * *} \\
(0.016)\end{array}$ \\
\hline 3 & $\begin{array}{l}-0.079^{*} \\
(0.036)\end{array}$ & $\begin{array}{c}-0.107^{* * * *} \\
(0.020)\end{array}$ & $\begin{array}{l}-0.226^{* * * *} \\
(0.03)^{*}\end{array}$ & $\begin{array}{l}-0.471^{* * * *} \\
(0.016)\end{array}$ & $\begin{array}{l}-4.842^{* * * *} \\
(0.784)\end{array}$ & $\begin{array}{l}-12.955^{* * * *} \\
(0.547)\end{array}$ & $\begin{array}{l}-0.132^{*+* *} \\
(0.03)^{2}\end{array}$ & $\begin{array}{l}-0.435^{* * * *} \\
(0.017)\end{array}$ & $-0.132 * * *$ & $-0.435^{* * *}$ \\
\hline 4 & $\begin{array}{l}-0.084^{*} \\
(0.037)\end{array}$ & $\begin{array}{c}-0.163^{* * * *} \\
(0.020)\end{array}$ & $\begin{array}{c}-0.183^{* * * *} \\
(0.031)\end{array}$ & $\begin{array}{c}-0.428^{* * * *} \\
(0.017)\end{array}$ & $\begin{array}{l}-4.829^{* * * *} \\
(0.822)\end{array}$ & $\begin{array}{c}-13.210^{* * * *} \\
(0.537)\end{array}$ & $\begin{array}{c}-0.120^{* * * *} \\
(0.029)\end{array}$ & $\begin{array}{c}-0.402^{* * * *} \\
(0.017)\end{array}$ & $\begin{array}{c}-0.120 * * * \\
(0.029)\end{array}$ & $\begin{array}{c}-0.402^{* * *} \\
(0.017)\end{array}$ \\
\hline 5 & $\begin{array}{c}-0.146^{* * * *} \\
(0.041)\end{array}$ & $\begin{array}{c}-0.187^{* * * *} \\
(0.019)\end{array}$ & $\begin{array}{c}-0.193^{* * * *} \\
(0.032)\end{array}$ & $\begin{array}{c}-0.388^{* * *} \\
(0.017)\end{array}$ & $\begin{array}{c}-3.121^{* * * *} \\
(0.769)\end{array}$ & $\begin{array}{c}-13.243^{* *+* *} \\
(0.507)\end{array}$ & $\begin{array}{c}-0.104^{* * * *} \\
(0.029)\end{array}$ & $\begin{array}{c}-0.370^{* * * *} \\
(0.017)\end{array}$ & $\begin{array}{c}-0.1024 * * * \\
(0.029)\end{array}$ & $\begin{array}{c}-0.370^{* * *} \\
(0.017)\end{array}$ \\
\hline 6 & $\begin{array}{c}-0.134^{* * * *} \\
(0.040)\end{array}$ & $\begin{array}{c}-0.198^{* * * *} \\
(0.020)\end{array}$ & $\begin{array}{c}-0.182^{* * * *} \\
(0.033)\end{array}$ & $\begin{array}{c}-0.383^{* * * *} \\
(0.017)\end{array}$ & $\begin{array}{c}-3.889^{* * * *} \\
(0.808)\end{array}$ & $\begin{array}{c}-13.272^{* * * *} \\
(0.521)\end{array}$ & $\begin{array}{l}-0.096^{* * *} \\
(0.030)\end{array}$ & $\begin{array}{c}-0.356^{* * * *} \\
(0.017)\end{array}$ & $\begin{array}{c}-0.096 * * \\
(0.030)\end{array}$ & $\begin{array}{c}-0.356^{* * *} \\
(0.017)\end{array}$ \\
\hline 7 & $\begin{array}{l}-0.127^{* *} \\
(0.042)\end{array}$ & $\begin{array}{l}-0.221^{* * * *} \\
(0.020)\end{array}$ & $\begin{array}{l}-0.184^{* * * *} \\
(0.033)\end{array}$ & $\begin{array}{l}-0.357^{* * * *} \\
(0.018)\end{array}$ & $\begin{array}{l}-3.475^{* * * *} \\
(0.84)\end{array}$ & $\begin{array}{l}-13.411^{* * * * *} \\
(0.528)\end{array}$ & $\begin{array}{l}-0.100^{* * * *} \\
(0.030)\end{array}$ & $\begin{array}{l}-0.336^{* * * *} \\
(0.017)\end{array}$ & $\begin{array}{c}-0.108 * * * \\
(0.030)\end{array}$ & $\begin{array}{l}-0.336 * * * \\
(0.017)\end{array}$ \\
\hline 8 & $\begin{array}{l}-0.131^{* * *} \\
(0.042)\end{array}$ & $\begin{array}{c}-0.222^{* * * *} \\
(0.021)\end{array}$ & $\begin{array}{c}-0.198^{* * * *} \\
(0.034)\end{array}$ & $\begin{array}{c}-0.365^{* * * *} \\
(0.019)\end{array}$ & $\begin{array}{c}-4.026^{* * * *} \\
(0.861)\end{array}$ & $\begin{array}{c}-13.572^{* * * *} \\
(0.541)\end{array}$ & $\begin{array}{l}-0.092^{* * *} \\
(0.031)\end{array}$ & $\begin{array}{c}-0.332^{* * * *} \\
(0.018)\end{array}$ & $\begin{array}{c}-0.092 * * \\
(0.031)\end{array}$ & $\begin{array}{c}-0.332^{* * *} \\
(0.018)\end{array}$ \\
\hline 9 & $\begin{array}{l}-0.148^{* * *} \\
(0.047\end{array}$ & $\begin{array}{l}-0.268^{* * * *} \\
(0.022)\end{array}$ & $\begin{array}{l}-0.181^{* * * *} \\
(0.036\end{array}$ & $\begin{array}{l}-0.363^{* * *} \\
(0.019)\end{array}$ & $\begin{array}{l}-3.270^{* * * *} \\
(0.844)\end{array}$ & $\begin{array}{l}-13.243^{* * * * *} \\
(0.559)\end{array}$ & $\begin{array}{l}-0.076^{*} \\
(0.031)\end{array}$ & $\begin{array}{l}-0.334^{* * * *} \\
(0.019)\end{array}$ & $-0.076^{*}$ & $\begin{array}{l}-0.334 * * * \\
(0.019)\end{array}$ \\
\hline 10 & $\begin{array}{c}-0.156^{* * *} \\
(0.047)\end{array}$ & $\begin{array}{c}-0.274^{* * * *} \\
(0.023)\end{array}$ & $\begin{array}{c}-0.195^{* * * *} \\
(0.037)\end{array}$ & $\begin{array}{c}-0.342^{* * * *} \\
(0.020)\end{array}$ & $\begin{array}{l}-2.787^{* *} \\
(0.870)\end{array}$ & $\begin{array}{c}-12.754^{* * *} \\
(0.567)\end{array}$ & $\begin{array}{l}-0.070^{*} \\
(0.032)\end{array}$ & $\begin{array}{c}-0.313^{* * * *} \\
(0.019)\end{array}$ & $\begin{array}{l}-0.070^{*} \\
(0.032)\end{array}$ & $\begin{array}{c}-0.313^{* * *} \\
(0.019)\end{array}$ \\
\hline 11 & $\begin{array}{l}-0.179^{* * * *} \\
(0.048)\end{array}$ & $\begin{array}{l}-0.277^{* * * *} \\
(0.023)\end{array}$ & $\begin{array}{l}-0.168^{* * * * *} \\
(0.03)^{2}\end{array}$ & $\begin{array}{l}-0.325^{* * * *} \\
(0.020)\end{array}$ & $\begin{array}{l}-3.003^{* * * *} \\
(0.890)\end{array}$ & $\begin{array}{l}-13.008^{* * * * *} \\
(0.588)\end{array}$ & $\begin{array}{l}-0.050 \\
-0.033)\end{array}$ & $-0.302^{* * * *}$ & $\begin{array}{l}-0.050 \\
-0.033\end{array}$ & $\begin{array}{l}-0.302 * * * \\
(0.020 *\end{array}$ \\
\hline 12 & $\begin{array}{c}-0.194^{* * * *} \\
(0.049)\end{array}$ & $\begin{array}{c}-0.283^{* * * *} \\
(0.024)\end{array}$ & $\begin{array}{c}-0.151^{* * * *} \\
(0.040)\end{array}$ & $\begin{array}{c}-0.323^{* * * *} \\
(0.021)\end{array}$ & $\begin{array}{l}-2.894^{* *} \\
(0.894)\end{array}$ & $\begin{array}{c}-12.012^{* * * *} \\
(0.609)\end{array}$ & $\begin{array}{l}-0.033 \\
(0.034)\end{array}$ & $\begin{array}{c}-0.297^{* * * *} \\
(0.020)\end{array}$ & $\begin{array}{l}-0.033 \\
(0.034)\end{array}$ & $\begin{array}{c}-0.2977^{* * * *} \\
(0.020)\end{array}$ \\
\hline 13 & $-0.178^{* * *}$ & $\begin{array}{l}-0.326^{* * * *} \\
(0.025)\end{array}$ & $-0.182^{* * * *}$ & $\begin{array}{l}-0.319^{* * * *} \\
(0.022)\end{array}$ & $\begin{array}{l}-2.517^{* *} \\
(0.945)\end{array}$ & $\begin{array}{l}-11.699^{* * * * *} \\
(0.632)\end{array}$ & $\begin{array}{r}-0.058 \\
-0.034)\end{array}$ & $-0.286^{* * * *}$ & $\begin{array}{r}-0.058 \\
-0.034\end{array}$ & $-0.286^{* * * *}$ \\
\hline 14 & $-0.209^{* * * *}$ & $-0.327^{* * * *}$ & $-0.189^{* * * *}$ & $-0.307^{* * * *}$ & -1.477 & $-10.881^{* * * *}$ & -0.059 & $-0.279^{* * * *}$ & -0.059 & $-0.279 * * *$ \\
\hline 15 & $\begin{array}{l}(0.053) \\
-0.232^{* * *}\end{array}$ & $\begin{array}{l}(0.025) \\
-0.334^{* * *}\end{array}$ & $\begin{array}{c}(0.042) \\
-0.167^{* * *}\end{array}$ & $\begin{array}{c}(0.023) \\
-0.306^{* * *}\end{array}$ & $\begin{array}{l}(0.944) \\
-2.164^{*}\end{array}$ & $\begin{array}{c}(0.655) \\
-10.733^{* * * *}\end{array}$ & $\begin{array}{l}(0.036) \\
-0.062\end{array}$ & $\begin{array}{l}(0.022) \\
-0.282^{* * *}\end{array}$ & $\begin{array}{l}(0.036) \\
-0.062\end{array}$ & $\begin{array}{c}(0.022) \\
-0.282^{* * * *}\end{array}$ \\
\hline & $(0.055)$ & $(0.026)$ & $(0.044)$ & $(0.024)$ & $(1.015)$ & $(0.678)$ & $(0.036)$ & $(0.023)$ & $(0.036)$ & $(0.023)$ \\
\hline Observations & 5963 & 16425 & 9957 & 31364 & 5752 & 15633 & 9957 & 31364 & 9957 & 31364 \\
\hline
\end{tabular}

Standard errors in parentheses; ${ }^{*} p<0.05,{ }^{* *} p<0.01,{ }^{* * *} p<0.001$ 
TABLE A 3: : REgRESSION RESULTS CORRESPONDING TO FIG. 7 AND 8

\begin{tabular}{|c|c|c|c|c|c|c|c|}
\hline & $\begin{array}{l}\text { (1) } \\
\text { LFP }\end{array}$ & $\begin{array}{l}\text { (2) } \\
\text { Preferred LFP }\end{array}$ & $\begin{array}{l}3) \\
\text { Difference in } \\
\text { preferred and } \\
\text { realized LFP }\end{array}$ & $\begin{array}{l}\text { (4) } \\
\text { Working hours }\end{array}$ & $\begin{array}{l}\text { (5) } \\
\text { Preferred working } \\
\text { hours }\end{array}$ & $\begin{array}{l}6) \\
\text { Difference in } \\
\text { preferred and } \\
\text { realized working } \\
\text { hours }\end{array}$ & $\begin{array}{l}\text { (7) } \\
\text { Time spent for } \\
\text { childcare (Fig 8) }\end{array}$ \\
\hline \multicolumn{8}{|l|}{ Child age \# Group } \\
\hline$-5 /-1$ \# East to West & $\begin{array}{l}0.878 * * * \\
(0.063)\end{array}$ & $\begin{array}{l}0.914 * * * \\
(0.053)\end{array}$ & $\begin{array}{l}0.036 \\
(0.028)\end{array}$ & $\begin{array}{l}42.599 * * * \\
(1.051)\end{array}$ & $\begin{array}{l}37.986 * * * \\
(1.060)\end{array}$ & $\begin{array}{l}-4.613^{* * *} \\
(1.018)\end{array}$ & $\begin{array}{l}-1.142 \\
(2.452)\end{array}$ \\
\hline$-5 /-1$ \# East & $\begin{array}{l}0.854 * * * \\
(0.028)\end{array}$ & $\begin{array}{l}0.926^{* * *} \\
(0.021)\end{array}$ & $\begin{array}{l}0.072 * * * \\
(0.016)\end{array}$ & $\begin{array}{l}41.169^{* * *} \\
(0.613)\end{array}$ & $\begin{array}{l}36.982^{* * *} \\
(0.528)\end{array}$ & $\begin{array}{l}-4.187^{* * *} \\
(0.668)\end{array}$ & $\begin{array}{l}-3.143^{* * * *} \\
(0.627)\end{array}$ \\
\hline$-5 /-1$ at \# West & $\begin{array}{l}0.957^{* * *} \\
(0.011)\end{array}$ & $\begin{array}{l}0.971 * * * \\
(0.010)\end{array}$ & $\begin{array}{l}0.014^{* *} \\
(0.005)\end{array}$ & $\begin{array}{l}40.017^{* * *} \\
(0.354)\end{array}$ & $\begin{array}{l}34.531^{* * *} \\
(0.290)\end{array}$ & $\begin{array}{l}-5.486 * * * \\
(0.285)\end{array}$ & $\begin{array}{l}-4.601^{* * *} \\
(0.508)\end{array}$ \\
\hline \multicolumn{8}{|l|}{ After Childbirth } \\
\hline $0 / 2$ \# East to West & $\begin{array}{l}0.338^{* * *} \\
(0.069)\end{array}$ & $\begin{array}{l}0.362^{* * *} \\
(0.067)\end{array}$ & $\begin{array}{l}0.025 \\
(0.022)\end{array}$ & $\begin{array}{l}33.509^{* * *} \\
(4.741)\end{array}$ & $\begin{array}{l}32.293^{* * *} \\
(3.562)\end{array}$ & $\begin{array}{l}-1.215 \\
(2.156)\end{array}$ & $\begin{array}{l}49.725^{* * *} \\
(5.135)\end{array}$ \\
\hline 0/2 \# East & $\begin{array}{l}0.363^{* * *} \\
(0.023)\end{array}$ & $\begin{array}{l}0.447^{* * * *} \\
(0.023)\end{array}$ & $\begin{array}{l}0.084^{* * *} \\
(0.013)\end{array}$ & $\begin{array}{l}33.819^{* * *} \\
(1.038)\end{array}$ & $\begin{array}{l}32.157^{* * *} \\
(0.615)\end{array}$ & $\begin{array}{l}-1.662 \\
(0.940)\end{array}$ & $\begin{array}{l}40.984^{* * *} \\
(1.552)\end{array}$ \\
\hline $0 / 2$ at \# West & $\begin{array}{l}0.312^{* * * *} \\
(0.010)\end{array}$ & $\begin{array}{l}0.339^{* * * *} \\
(0.011)\end{array}$ & $\begin{array}{l}0.027^{* * * *} \\
(0.004)\end{array}$ & $\begin{array}{l}23.735^{* * *} \\
(0.529)\end{array}$ & $\begin{array}{l}23.476^{* * *} \\
(0.440)\end{array}$ & $\begin{array}{l}-0.259 \\
(0.331)\end{array}$ & $\begin{array}{l}51.891^{* * *} \\
(0.733)\end{array}$ \\
\hline 3/5 at \# East to West & $\begin{array}{l}0.600^{* * * *} \\
(0.065)\end{array}$ & $\begin{array}{l}0.727^{* * *} \\
(0.061)\end{array}$ & $\begin{array}{l}0.127^{* * *} \\
(0.033)\end{array}$ & $\begin{array}{l}30.476^{* * *} \\
(1.804)\end{array}$ & $\begin{array}{l}29.317^{* * *} \\
(1.395)\end{array}$ & $\begin{array}{l}-1.159 \\
(1.188)\end{array}$ & $\begin{array}{l}35.539^{* * *} \\
(3.334)\end{array}$ \\
\hline 3/5 \# East & $\begin{array}{l}0.626^{* * * *} \\
(0.023)\end{array}$ & $\begin{array}{l}0.759^{* * * *} \\
(0.021)\end{array}$ & $\begin{array}{l}0.133^{* * * *} \\
(0.015)\end{array}$ & $\begin{array}{l}35.262^{* * *} \\
(0.759)\end{array}$ & $\begin{array}{l}32.507^{* * *} \\
(0.476)\end{array}$ & $\begin{array}{l}-2.755^{* * *} \\
(0.608)\end{array}$ & $\begin{array}{l}28.319^{* * *} \\
(1.053)\end{array}$ \\
\hline 3/5 \# West & $\begin{array}{l}0.469^{* * *} \\
(0.011)\end{array}$ & $\begin{array}{l}0.505^{* * *} \\
(0.011)\end{array}$ & $\begin{array}{l}0.036^{* * *} \\
(0.003)\end{array}$ & $\begin{array}{l}23.949^{* * *} \\
(0.376)\end{array}$ & $\begin{array}{l}23.230^{* * *} \\
(0.305)\end{array}$ & $\begin{array}{l}-0.719^{* * *} \\
(0.218)\end{array}$ & $\begin{array}{l}46.546^{* * *} \\
(0.642)\end{array}$ \\
\hline 6/10 \# East to West & $\begin{array}{l}0.684^{* * *} \\
(0.048)\end{array}$ & $\begin{array}{l}0.759^{* * *} \\
(0.042)\end{array}$ & $\begin{array}{l}0.076^{* * *} \\
(0.022)\end{array}$ & $\begin{array}{l}27.640^{* * *} \\
(1.506)\end{array}$ & $\begin{array}{l}29.480^{* * *} \\
(1.378)\end{array}$ & $\begin{array}{l}1.840 \\
(1.242)\end{array}$ & $\begin{array}{l}28.584^{* * *} \\
(1.968)\end{array}$ \\
\hline 6/10\# East & $\begin{array}{l}0.669^{* * * *} \\
(0.018)\end{array}$ & $\begin{array}{l}0.811^{* * * *} \\
(0.015)\end{array}$ & $\begin{array}{l}0.143^{* * *} \\
(0.011)\end{array}$ & $\begin{array}{l}36.305^{* * *} \\
(0.472)\end{array}$ & $\begin{array}{l}32.545^{* * *} \\
(0.350)\end{array}$ & $\begin{array}{l}-3.760^{* * *} \\
(0.413)\end{array}$ & $\begin{array}{l}26.687^{* * *} \\
(0.936)\end{array}$ \\
\hline 6/10 \# West & $\begin{array}{l}0.545^{* * *} \\
(0.009)\end{array}$ & $\begin{array}{l}0.585^{* * *} \\
(0.009)\end{array}$ & $\begin{array}{l}0.039^{* * *} \\
(0.003)\end{array}$ & $\begin{array}{l}23.482^{* * *} \\
(0.299)\end{array}$ & $\begin{array}{l}22.531^{* * *} \\
(0.231)\end{array}$ & $\begin{array}{l}-0.951^{* * *} \\
(0.176)\end{array}$ & $\begin{array}{l}40.868^{* * *} \\
(0.550)\end{array}$ \\
\hline 11/15 \# East to West & $\begin{array}{l}0.735^{* * *} \\
(0.037)\end{array}$ & $\begin{array}{l}0.814^{* * * *} \\
(0.031)\end{array}$ & $\begin{array}{l}0.079^{* * *} \\
(0.020)\end{array}$ & $\begin{array}{l}30.662^{* * *} \\
(1.278)\end{array}$ & $\begin{array}{l}29.763^{* * *} \\
(1.088)\end{array}$ & $\begin{array}{l}-0.900 \\
(0.727)\end{array}$ & $\begin{array}{l}24.949^{* * *} \\
(2.401)\end{array}$ \\
\hline 11/15\# East & $\begin{array}{l}0.702^{* * *} \\
(0.016)\end{array}$ & $\begin{array}{l}0.847^{* * * *} \\
(0.011)\end{array}$ & $\begin{array}{l}0.145^{* * *} \\
(0.011)\end{array}$ & $\begin{array}{l}37.503^{* * *} \\
(0.384)\end{array}$ & $\begin{array}{l}34.170^{* * *} \\
(0.274)\end{array}$ & $\begin{array}{l}-3.332^{* * *} \\
(0.315)\end{array}$ & $\begin{array}{l}21.315^{* * *} \\
(0.712)\end{array}$ \\
\hline 11/15 \# West & $\begin{array}{l}0.591^{* * * *} \\
(0.011)\end{array}$ & $\begin{array}{l}0.630^{* * *} \\
(0.011)\end{array}$ & $\begin{array}{l}0.039^{* * *} \\
(0.003)\end{array}$ & $\begin{array}{l}24.626^{* * *} \\
(0.339)\end{array}$ & $\begin{array}{l}23.759^{* * *} \\
(0.255)\end{array}$ & $\begin{array}{l}-0.868^{* * *} \\
(0.201)\end{array}$ & $\begin{array}{l}31.950^{* * *} \\
(0.611)\end{array}$ \\
\hline Observations & 32906 & 32906 & 32906 & 18055 & 18055 & 18055 & 32178 \\
\hline
\end{tabular}


TABLE A 4: : REgRESSION RESULTS CORRESPONDING TO FIG. A1

\begin{tabular}{|c|c|c|}
\hline & $\begin{array}{c}(1) \\
\text { Monthly wages } \\
\text { East }\end{array}$ & $\begin{array}{c}(2) \\
\text { Monthly wages } \\
\text { - West } \\
\end{array}$ \\
\hline \multicolumn{3}{|l|}{ Time to childbirth } \\
\hline-5 & $\begin{array}{c}-2.676 \\
(68.866)\end{array}$ & $\begin{array}{c}11.627 \\
(48.955)\end{array}$ \\
\hline-4 & $\begin{array}{l}104.298 \\
(59.930)\end{array}$ & $\begin{array}{c}111.383^{* *} \\
(43.156)\end{array}$ \\
\hline-3 & $\begin{array}{l}116.573^{*} \\
(49.402)\end{array}$ & $\begin{array}{c}140.226^{* * *} \\
(37.793)\end{array}$ \\
\hline-2 & $\begin{array}{l}126.408^{* *} \\
(41.672)\end{array}$ & $\begin{array}{c}170.180^{* * *} \\
(31.577)\end{array}$ \\
\hline-1 & Ref & \\
\hline 0 & $\begin{array}{c}-1115.415^{* * *} \\
(57.336)\end{array}$ & $\begin{array}{c}-1667.603^{* * *} \\
(38.929)\end{array}$ \\
\hline 1 & $\begin{array}{c}-723.108^{* * *} \\
(50.926)\end{array}$ & $\begin{array}{c}-1513.568^{* * *} \\
(38.312)\end{array}$ \\
\hline 2 & $\begin{array}{c}-486.322^{* * * *} \\
(54.373)\end{array}$ & $\begin{array}{c}-1392.310^{* * *} \\
(41.570)\end{array}$ \\
\hline 3 & $\begin{array}{c}-502.052^{* * *} \\
(58.500)\end{array}$ & $\begin{array}{c}-1349.686^{* * *} \\
(42.749)\end{array}$ \\
\hline 4 & $\begin{array}{c}-408.686^{* * *} \\
(62.589)\end{array}$ & $\begin{array}{c}-1296.016^{* * *} \\
(43.856)\end{array}$ \\
\hline 5 & $\begin{array}{c}-432.339^{* * *} \\
(66.907)\end{array}$ & $\begin{array}{c}-1267.941^{* * *} \\
(44.424)\end{array}$ \\
\hline 6 & $\begin{array}{c}-400.927^{* * *} \\
(70.980)\end{array}$ & $\begin{array}{c}-1253.321^{* * *} \\
(47.990)\end{array}$ \\
\hline 7 & $\begin{array}{c}-417.781^{* * *} \\
(74.324)\end{array}$ & $\begin{array}{c}-1191.040^{* * *} \\
(58.369)\end{array}$ \\
\hline 8 & $\begin{array}{c}-436.818^{* * *} \\
(77.885)\end{array}$ & $\begin{array}{c}-1220.334^{* * *} \\
(58.248)\end{array}$ \\
\hline 9 & $\begin{array}{c}-387.310^{* * *} \\
(91.851)\end{array}$ & $\begin{array}{c}-1202.218^{* * *} \\
(64.947)\end{array}$ \\
\hline 10 & $\begin{array}{c}-443.247^{* * *} \\
(87.016)\end{array}$ & $\begin{array}{c}-1183.506^{* * *} \\
(56.376)\end{array}$ \\
\hline 11 & $\begin{array}{c}-393.715^{* * *} \\
(89.948)\end{array}$ & $\begin{array}{c}-1181.352^{* * *} \\
(60.003)\end{array}$ \\
\hline 12 & $\begin{array}{c}-404.441^{* * *} \\
(93.836)\end{array}$ & $\begin{array}{c}-1176.132^{* * *} \\
(60.731)\end{array}$ \\
\hline 13 & $\begin{array}{c}-432.811^{* * *} \\
(98.265)\end{array}$ & $\begin{array}{c}-1193.115^{* * *} \\
(61.404)\end{array}$ \\
\hline 14 & $\begin{array}{c}-447.410^{* * *} \\
(102.260)\end{array}$ & $\begin{array}{c}-1156.398^{* * *} \\
(63.811)\end{array}$ \\
\hline 15 & $\begin{array}{c}-455.823^{* * *} \\
(106.321)\end{array}$ & $\begin{array}{c}-1156.459^{* * *} \\
(66.328)\end{array}$ \\
\hline Observations & 9957 & 31364 \\
\hline
\end{tabular}




\section{Appendix B: The childcare expansion in West Germany}

To ensure that the effect that we find in our main analysis is not driven by differences in the supply in subsidized childcare, we investigate whether the expansion in subsidized childcare in West Germany led to changes in motherhood penalties. During the mid 2000s, Germany increased the supply in subsidized childcare slots with the endpoint being a legal claim to a subsidized childcare slot for children aged one and two from 1 August 2013 onwards. While the supply of subsidized childcare in East Germany is, as described in the text, generally high, the reforms especially lead West German states to hugely expand the supply of formal childcare slots. We have data on the provision of subsidized childcare for 72 West German NUTS2-regions and use this data to investigate the effect of the expansion of subsidized childcare on maternal labor market outcomes in West Germany. We accomplish this by splitting the sample into regions that expanded their supply in formal childcare above or below the West German median from 2002 to 2010.

Figure B1 shows the childcare ratio (i.e. the share of early childcare slots in a region divided by the number of under 3-year-olds in the same region), split on the median of the expansion in subsidized chilcare in West Germany. As can be seen, before 2002, there was practically no subsidized early childcare in West Germany. This drastically changed over time, but still with substantial variation between regions, thus increasing the difference in the provision of early childcare slots from 2 percentage point in 2002 between both groups to 7 percentage points in 2010 .

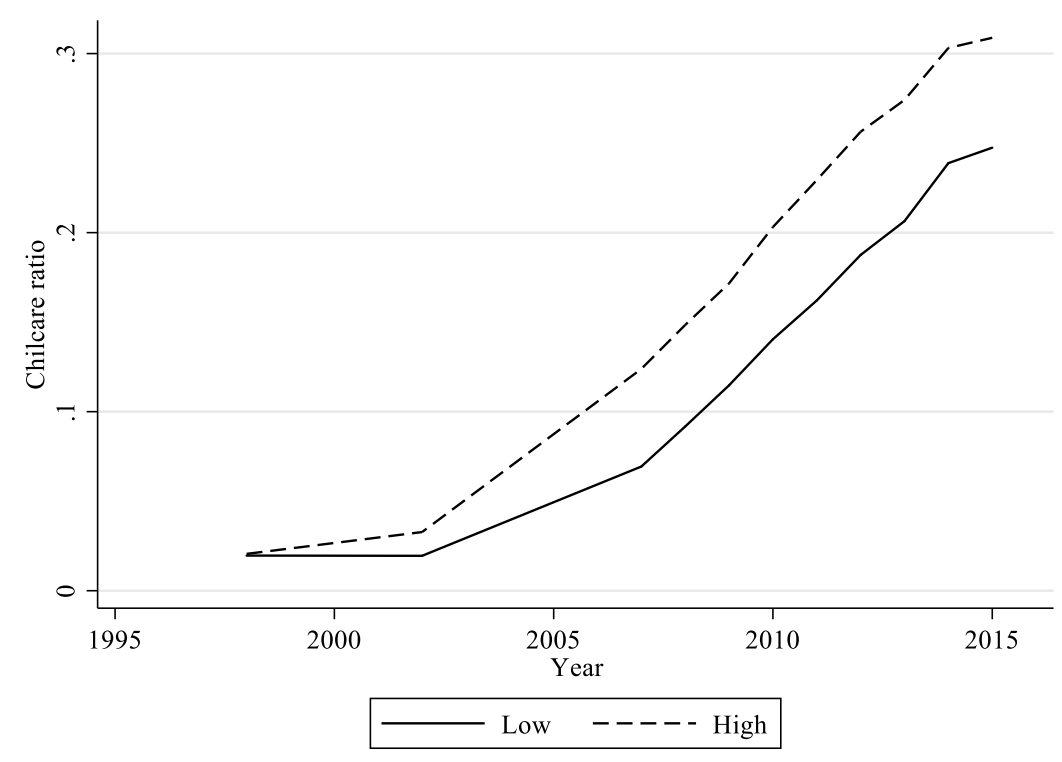

Figure B 1: Childcare Supply for under 3-year-olds For Regions with High (above the West German Median) and Low (Below this threshold) 
To investigate whether the childcare expansion had any effect on motherhood penalties, we split our sample by regions that expanded their childcare supply above or below the West German median as well as by period. Specifically, we compare the two groups from 1996 to 2002 (where there was practically no subsidized childcare for under 3-year-olds and where we have information on childcare to begin with) and from 2010 to 2016 (where substantial differences emerged). This strategy resembles Havnes and Mogstad (2010). Figure B2 shows the results prior to childcare expansion. As expected, the motherhood penalties do not differ between the groups as there is practically no difference in subsidized childcare slots.
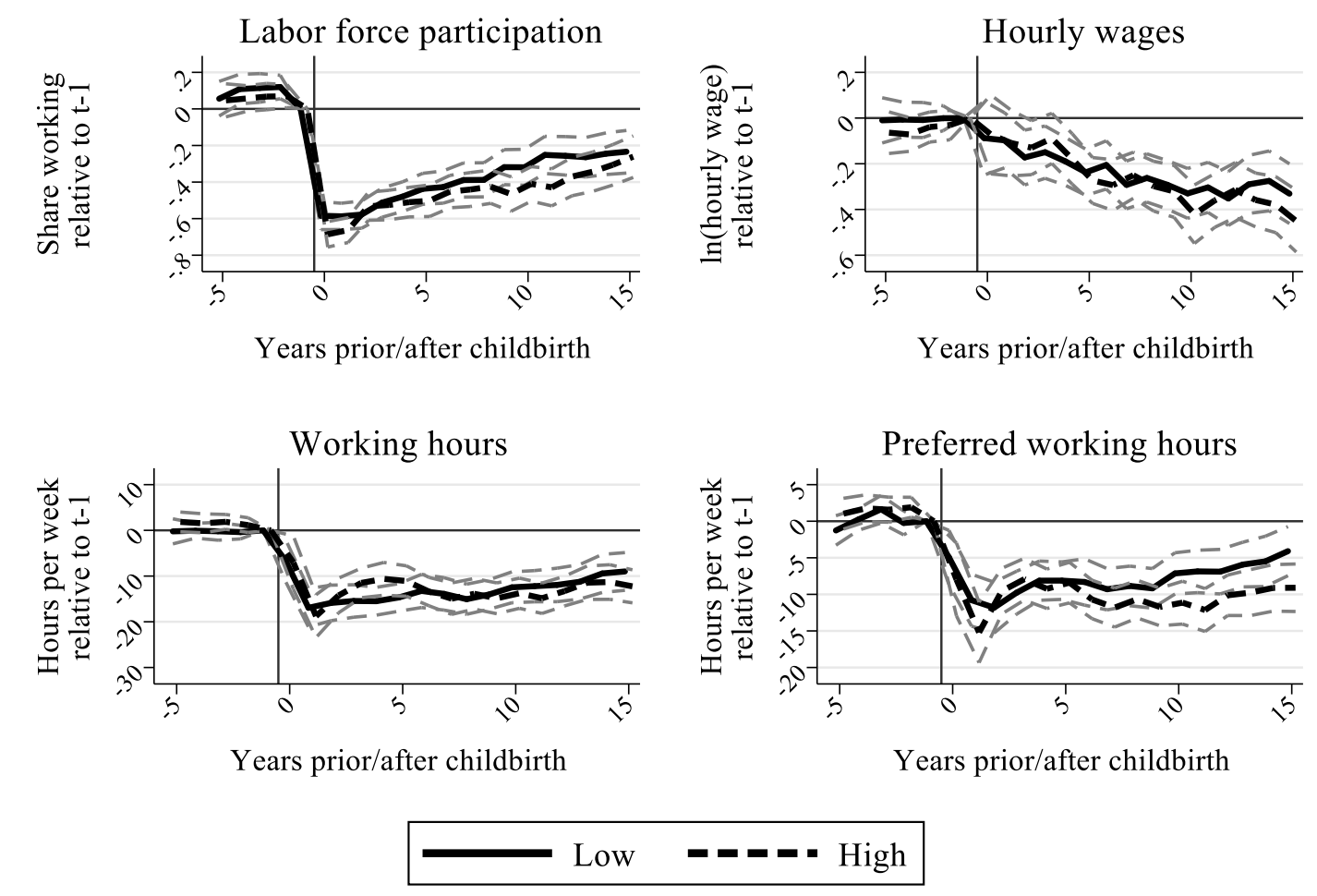

2002: Low ratio: .02; high ratio: .04. Results 1996-2002

Figure B 2: Motherhood Penalties before childcare expansion

In the next step, we investigate motherhood penalties after the childcare expansion. In this period, a substantial difference of 7 percentage points regarding the supply of subsidized childcare has emerged. Figure B3 shows the results of the estimations. As can be seen, there is still no significant difference between the two groups. Furthermore, we are even likely to overestimate the differences if the childcare expansion is driven by mothers demand for childcare slots and we would thus expect regions with mothers with a higher attachment to the labor market to more quickly expand childcare. However, we still find no effect. We take this as evidence that differences in early childcare supply between regions cannot explain motherhood penalties. 

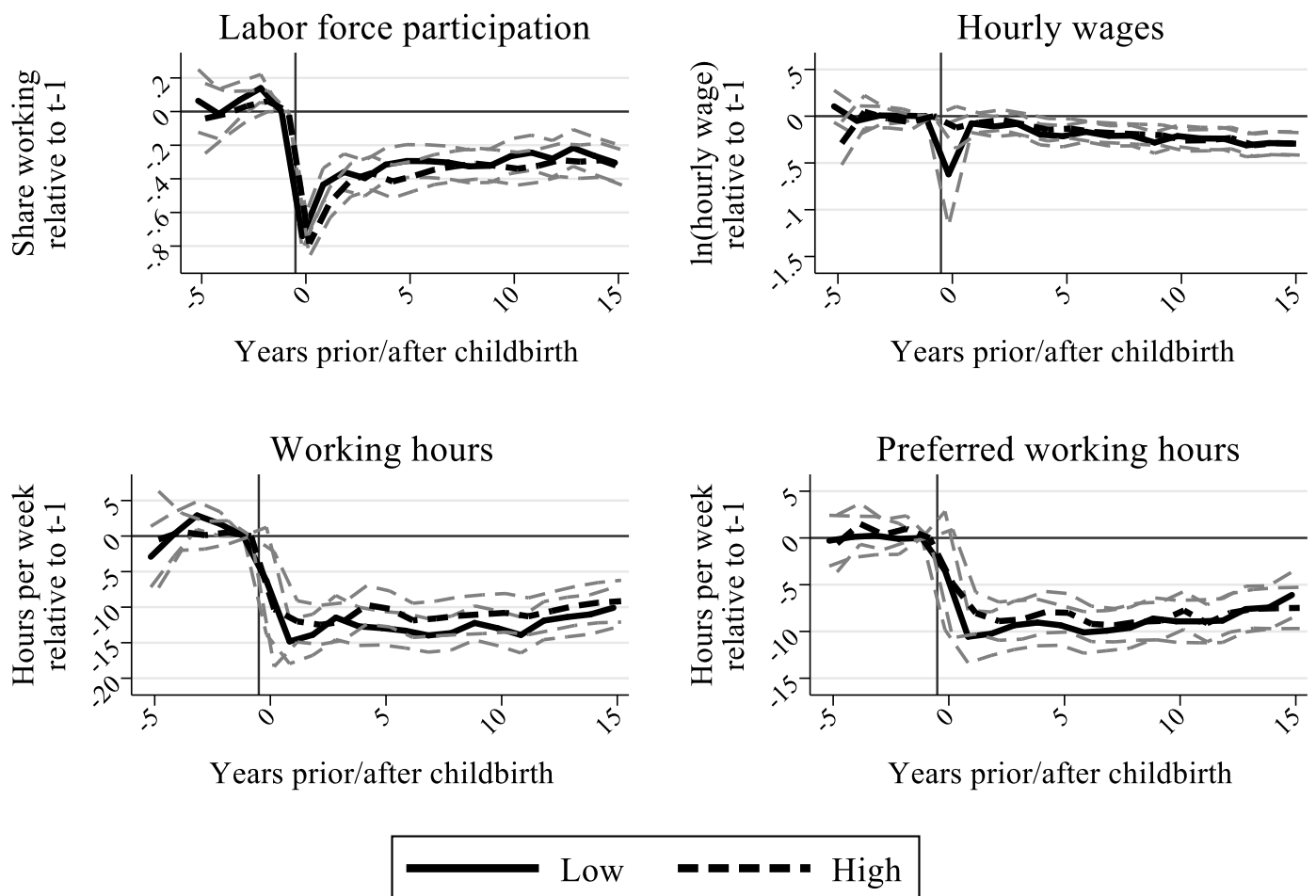

2010: Low ratio: .14; high ratio: .21. Results 2010-2016

Figure B 3: Motherhood penalties after childcare expansion 